\title{
THE CRIME-TERROR NEXUS IN CANADA: CHANGING HUMAN TRAFFICKING AND SMUGGLING OPERATIONS
}

\author{
by
}

Moses Kay-Leun Wong, B.A., Ryerson University, 2013

\author{
A Major Research Paper \\ presented to Ryerson University \\ in partial fulfillment of the requirements for the degree of \\ Master of Arts \\ in the program of \\ Immigration and Settlement Studies
}

Toronto, Ontario, Canada, 2014

CMoses Kay-Leun Wong 2014 


\section{AUTHOR'S DECLARATION FOR ELECTRONIC SUBMISSION OF A MAJOR RESEARCH PAPER}

(MRP)

I hereby declare that I am the sole author of this MRP. This is a true copy of the MRP, including any required final revisions, as accepted by my examiners. I authorize Ryerson University to lend this MRP to other institutions or individuals for the purpose of scholarly research. I further authorize Ryerson University to reproduce this MRP by photocopying or by other means, in total or in part, at the request of other institutions or individuals for the purpose of scholarly research. I understand that my MRP may be made electronically available to the public. 


\title{
THE CRIME-TERROR NEXUS IN CANADA: CHANGING HUMAN TRAFFICKING OPERATIONS AND SMUGGLING \\ Moses Wong \\ Master of Arts, 2014 \\ Immigration and Settlement Studies \\ Ryerson University
}

\begin{abstract}
$\underline{\text { Abstract }}$
In the post-9/11 era, the Canadian and the United States government are facing two phenomena, Narco-Terrorism and Crime-Terror Nexus. Terrorist groups and transnational organized crime are aligning their illicit activities. This thesis will demonstrate how the convergence of these two clandestine enterprises changes human trafficking and smuggling operations, and thus pose a higher caliber threat to vulnerable populations, such as victims of trafficking and refugees. Links will be drawn to explain why Canada's current border security and refugee system are ill-equipped to address these nefarious activities. The thesis proposes recommendations offered by Canadian experts in the field of migration policy and international security. However, implementations depend heavily on how receptive Canada's general public is. The majority of Canadians are not aware that issues of human trafficking and smuggling and refugee are intertwined with border security, transnational organized crime, and now terrorist groups.
\end{abstract}

Key Words: Narco-Terrorism; Crime-Terror Nexus; Human Trafficking and Smuggling; Refugee; Border Security; National Security 


\section{$\underline{\text { Acknowledgements }}$}

I would like to thank my supervisor, mentor, and good friend, Professor Dr. Arne Kislenko, for inspiring and encouraging me to pursue this Masters degree. Thank you for your guidance and patience throughout my academic career: B.A. in Criminal Justice and MRP. I would also like to thank my family and close friends for your unconditional support; each and everyone of you is a blessing to my life. 


\section{Table of Contents}

Author's Declaration $\quad$ ii

$\begin{array}{ll}\text { Abstract } & \text { iii }\end{array}$

Acknowledgements $\quad$ iv

$\begin{array}{ll}\text { Introduction } & 1\end{array}$

$\begin{array}{lr}\text { Trafficking and Smuggling } & 2-6\end{array}$

$\begin{array}{lr}\text { The Palermo Protocol } & 6-10\end{array}$

Structures of Transnational Organized Crime $\quad 10-14$

Narco-Terrorism and The Crime-Terror Nexus $\quad 14-20$

Issues in Collecting Data on Trafficked Victims $\quad 21-24$

Migration Theories and Human Trafficking and Smuggling $\quad 24-26$

$\begin{array}{lr}\text { The Mechanics of Human Trafficking Operations } & 26-37\end{array}$

$\begin{array}{lr}\text { Immigration and Threats to National Security } & 37-49\end{array}$

$\begin{array}{lr}\text { Recommendations and Challenges } & 49-57\end{array}$

$\begin{array}{lr}\text { Conclusion } & 57-58\end{array}$

$\begin{array}{lr}\text { Bibliography } & 59-64\end{array}$ 


\section{Introduction}

Human trafficking is the "recruitment, transportation, and harbouring of an individual for the purposes of forced services"1. Forced services range forced labor to sexual exploitation. It is a heinous crime that can operate on local, national, and international levels. Men, women, and children are potential victims of human trafficking. This criminal activity has immense ramifications for the victims, citizens, and states. Human trafficking produces an annual profit of U.S. $\$ 7$ to $\$ 10$ million. Up to two million people are annually trafficked across national borders, the majority of whom are females trafficked for the purpose of sexual exploitation ${ }^{2}$. Due to how lucrative human trafficking is, the United Nations (UN) ranks it the third largest international crime after human smuggling and the trafficking of drugs and firearms ${ }^{3}$. Complicating the issue is that in the post-9/11 era, the Canadian and the United States (U.S.) governments are facing two phenomena, Narco-Terrorism and the Crime-Terror Nexus. Terrorist groups and transnational organized crime (TOC) are aligning their illicit activities. This thesis will demonstrate how the convergence of these two clandestine enterprises changes human trafficking and smuggling operations, and thus poses a higher caliber threat to vulnerable populations, such as victims of trafficking and refugees. Links will be drawn to explain why Canada's current border security and refugee system are ill-equipped to address these nefarious activities. The thesis proposes recommendations offered by Canadian experts in the field of migration policy and international security. However, implementation depends heavily on how receptive Canada's general public is. The majority of Canadians are not aware that issues of human trafficking and smuggling are intertwined with the immigration and refugee system, border security, transnational organized crime, and now terrorist groups.

\footnotetext{
${ }^{1}$ Laura Barnett, "Bill C-49 an Act to Amend the Criminal Code (Trafficking in persons) (Rev.ed)," Ottawa: Library of Parliament, Parliamentary Research Branch (2005): 2.

${ }^{2}$ April Rieger, "Missing the Mark: Why the Trafficking Victims Protection Act Fails to Protect Sex Trafficking Victims in the United States," Harvard Journal of Law \& Gender, no.30 (1) (2007): 231, accessed July 23, 2014, http://www.heinonline.org.ezproxy.lib.ryerson.ca/HOL/Page?page=231\&handle=hein.journals\%2Fhwlj30\&collecti on=journals\#235.

${ }^{3}$ John Winterdyk and Kelly Sundberg, "Human Trafficking: An International Tragedy,” Law Now 33, no.4 (2009): 1 .
} 


\section{Trafficking and Smuggling}

In any discussion on trafficking it is essential to first address legal definitions and distinctions.

The UN has crafted separate policies against human trafficking and human smuggling for States to sign and ratify. The Protocol to Prevent, Suppress and Punish Trafficking in Persons, Especially Women and Children, hereinafter called the Palermo Protocol, was adopted in 2000 and entered into force on December 25, 2003 to address the issues of human trafficking. To deal with human smuggling, the Protocol Against the Smuggling of Migrants by Land, Sea, and Air, hereinafter called Smuggling Protocol, was adopted in 2000 and entered into force on January 28, 2004. Article 3 of the Palermo Protocol defines human trafficking as:

"the recruitment, transportation, transfer harbouring or receipt of persons, by means of the threat or use of force or other forms of coercion, of abduction, of fraud, of deception, of the abuse of power or of a position of vulnerability or of the giving or receiving of payments or benefits to achieve the consent of a person having control over another person, for the purpose of exploitation. Exploitation shall include, at a minimum, the exploitation of the prostitution of others or other forms of sexual exploitation...",

Article 3 of the of the Protocol Against Smuggling defines the smuggling of migrants as:

"the procurement, in order to obtain, directly or indirectly, a financial or other material benefit, of the illegal entry of a person into a State Party of which the person is not a national or a permanent resident; 'illegal entry' shall mean crossing borders without complying with the necessary requirements for legal entry in the receiving State; 'fraudulent travel or identity document' shall mean any travel or identity document: that has been falsely made or altered in some material way by anyone other than a person or agency lawfully authorized to make or issue the travel or identity document on behalf of a State; or that has been improperly issued or obtained through misrepresentation, corruption or duress or in any other unlawful manner; or that is being used by a person other than the rightful holder; 'vessel' shall mean any type of water craft, including non-displacement craft seaplanes, sued or capable of being used as a means of transportation on water, except a warship, naval auxiliary or other vessel owner or operated by a Government and used, for the time being, only a government non-commercial service."5

From a legal standpoint, there are two main differences between the Palermo Protocol and the Smuggling Protocol. Human smuggling only occurs when an individual pays someone to aid him or her to enter illegally into a destination country. Human trafficking, on the other hand, can operate within the

\footnotetext{
${ }^{4}$ United Nations, "Protocol to Prevent, Suppress and Punish Trafficking in Persons, especially Women and Children, Supplementing the United Nations Convention Against Transnational Organized Crime," UNCJN, July 24, 2014, http://ww.uncjin.org/Documents/Conventions/dcatoc/final_documents2/convention_\%20traff_eng.pdf.

${ }^{5}$ Ibid.
} 
same country the victim is trafficked from, or across borders. Consent is the second main difference. According to the Smuggling Protocol, a person has established a mutual economic relationship with the smuggler to enter illegally into the destination country. Once the illegal migrant has arrived into the destination country, and successfully paid the smuggler, their relationship comes to an end. On the contrary, there is no mutual relationship in human trafficking. Traffickers deceive and coerce victims into forced labor and/or sexual exploitation.

The two Protocols also lead to different legal punishments and remedies. For example, the Palermo Protocol contains regulations for the State to protect the victims of trafficking by providing them temporary residency and eligibility for permanent residency ${ }^{6}$. This is not applicable to the smuggled migrant as he or she is deemed an offender to the State. Though the two protocols distinguish a victim of trafficking and a person being smuggled, they do share some similarities. Both criminalize smugglers and traffickers because both use illegal means to enter the country without consent ${ }^{7}$. Legal technicalities are necessary to distinguish who is an offender of the State, and who needs protection. Unfortunately, the reality is that it is very difficult to draw the line.

People being smuggled and trafficked victims share many commonalities. They are not as easily identified as described in the two Protocols. Smuggling and trafficking are forms of illegal migration ${ }^{8}$. People being smuggled and trafficked victims are transported across the border with either proper or improper documentation and without the approval of the State. Both are criminal operations conducted by TOCs and even terrorist groups ${ }^{9}$. Poverty and limited economic opportunities are characteristics both victims of trafficking and persons being smuggled share. Many are either left vulnerable to traffickers to exploit or seek help from smugglers to find employment in another country. For example, the Fujian and

\footnotetext{
${ }^{6}$ Anja P. Jakobi, Common Goods \& Evil? (New York: Oxford University Press, 2013), 104.

${ }^{7}$ Ibid.

${ }^{8}$ Raimo Väyrynen, "Illegal Immigration, Human Trafficking, and Organized Crime." United Nations University/WIDER, no. 72 (2003):1-2.

${ }^{9}$ Ibid.
} 
Guangdong provinces in China are well known for smugglers and their criminal operations ${ }^{10}$. The lack of financial resources, educational training, and employment opportunities there forces many men to pay smugglers to take them to another country. It has been reported that $95 \%$ of those smuggled into the U.S. from the People's Republic of China are young males.

Human traffickers also take advantage of people living in politically unstable environments. This is certainly the case for Russia in the pre and post-Soviet era: another prime point of origin in international trafficking ${ }^{11}$. The country has undergone major socio-economic and political events during the $20^{\text {th }}$ and $21^{\text {st }}$ centuries, which will be further discussed in detail when explaining the Strippergate scandal below. The events nonetheless created an unstable environment (i.e. high poverty rate, corruption, and lack of government support) where Russian criminals thrive in the trafficking of women and children within and across borders. For example, many women in the Far East of Russia seek employment out of the country. Russian TOCs pose as agents to deceive these women into sexual exploitation. Familial responsibility is another characteristic that victims of trafficking and people being smuggled share. The majority of the men smuggled out of Fujian and Guangdong provinces send remittances to their families back in their home villages. This is the same for women in Russia. They are 'pillars of support of society...glorified as the mothers of Russia' ${ }^{12}$. Young women, many of whom are single mothers, are financially responsible to support their children and parents.

Smugglers and traffickers are TOCs that use the same methods to carry out their operations. Both depend on the usage of fraudulent documents to board commercial air flights. Fraudulent documents act as an armor to hide the true identity of the illegal migrants. In order to obtain fraudulent documents, bribing officials is often necessary. Thus, corruption is essential to conduct trafficking and smuggling operations. This is a case for Chinese and Russian TOCs. Chinese smugglers, also known as 'Snakeheads,' bribe low-ranking but crucial government officials who have access to the immigration

\footnotetext{
${ }^{10}$ Louise Shelley, "Russian and Chinese Trafficking: A Comparative Perspective," in Human Traffic and Transnational Crime: Eurasian and American Perspectives, ed. Sally Stoecker and Louise Shelley (Lanham, MD: Rowman \&Littlefield Publishers, Inc. 2005), 68.

${ }^{11}$ Sally Stoecker, "Human Trafficking: A New Challenge for Russia and the United States," 16.

${ }^{12}$ Louise Shelley, "Russian and Chinese Trafficking: A Comparative Perspective," 68.
} 
system. These officials include passport inspectors, staff who have access to passport applications, and officials issuing residential and or marriage certificates ${ }^{13}$. They are also involved with Hong Kong businessmen who fund the finances and local individuals with connections to government officials and law enforcers. Thus, bribery is part of the smuggling expense and a tool for networking. One Snakehead commented that, "we need to know all kinds of people and that's why our expense are so high. Whenever we go out to eat, drink, and have fun with women, we always pay the bills. Otherwise, how else you going to establish a good relationship with government officials?"14

In addition to using commercial air flights, TOCs use other similar transportation routes to bring their victims or clients into Canada. Chinese and Russian TOCs transport their clients or victims by boat or by crossing the border ${ }^{15}$. These TOCs can conduct their operations by hiding in their ethnic diaspora enclaves in North America. Underground tunnels from Mexico to the U.S. are a common method for TOCs and terrorist groups. These tunnels are often owned by smugglers acting as pay-toll officers to charge other criminal syndicates and terrorist groups to use their networks ${ }^{16}$.

The last similarity trafficking and smuggling share is that a person being smuggled easily can be trafficked for the purpose of forced labor or sexual exploitation. There are at least two possibilities. If the people being smuggled are unable to pay off their debt, the smuggler often forces them into forced labor or sexual exploitation. This is common for migrant women forced into prostitution, especially in Chinese and Vietnamese communities. In November 2009, there was a prominent case where Vietnamese and Chinese illegal migrants paid smugglers 7,000 to 10,000 Euros to transport them into Britain. The majority paid half of the cost and upon arrival were all forced to manufacture marijuana, beg, prostitute, and other nefarious activities ${ }^{17}$. Another scheme traffickers use to deceive their victims is to pose as smugglers. The person pays the smuggler to enter another country, but does not realize that s/he is

\footnotetext{
${ }^{13}$ Sheldon Zhang, Human Smuggling Organization, (San Diego: Stanford University Press, 2008), 121.

${ }^{14}$ Ibid.,122.

${ }^{15}$ Louise Shelley, "Russian and Chinese Trafficking: A Comparative Perspective," 70.

${ }^{16}$ Gert Vermuelen, Van Damme, and Wendy De Bondt, "Organised Crime Involvement in Trafficking in Persons and Smuggling of Migrants," (Portland, Oregon: Maklu, 2010), 59.

${ }^{17}$ Ibid., 62.
} 
deceived by the trafficker. Upon arrival, the trafficker seizes their passports and forces them into labor or sex work. Traffickers, posing as smugglers, can also unexpectedly increase the transportation price to a point that clients cannot afford. This type of coercion, known as debt bondage, forces victims to work for traffickers in forced labor or prostitution to pay off their debt. ${ }^{18}$

\section{The Palermo Protocol}

To differentiate between a person being trafficked and a person being smuggled is in reality difficult. Prior to the Palermo Protocol, human trafficking was conceptualized as human smuggling ${ }^{19}$. It began to change when Argentina brought up the issue of human trafficking during the negotiations in defining the United Nations Convention Against Transnational Organized Crime (UNTOC) ${ }^{20}$. It viewed the Convention on the Rights of the Child as purely a human rights-based approach to child pornography and trafficking, and not a balance with legal punishments against the perpetrators. The UN General Assembly resolution called for an ad hoc committee to develop a convention specifically to deal with trafficking of women and children. Argentina and the U.S. each proposed a draft in the committee. Argentina favored for the protocol to only apply for women and children, but the U.S. favored a broadened comprehensive definition of a trafficked victim. This sparked an international moral debate between non-government organizations (NGOs). A stark division was instantly drawn between the Human Rights Caucus and the Coalition Against Trafficking in Women (CATW $)^{21}$

The Human Rights Caucus argued that women have the ability to consent to prostitution as a legitimate form of labor. They did not want the protocol to reflect a patriarchal mindset that would patronize women's autonomy. One representative from the Human Rights Caucus states, “obviously, by definition, no one consents to abduction or forced labor, but an adult women is able to consent to engage

\footnotetext{
${ }^{18}$ Louise Shelley, "Russian and Chinese Trafficking: A Comparative Perspective," 66.

${ }^{19}$ Elzbieta M. Gozdziak \& Elizabeth A. Collett, "Research on Human Trafficking in North America: A Review of Literature," in Data and Research on Human Trafficking: A Global Survey 2005, ed. by Frank Lazko and Elzbieta Gozdziak (Geneva: International Organization for Migration, 2005), 103.

${ }^{20}$ Anja P. Jakobi, Common Goods \& Evil?, 166.

${ }^{21}$ Elzbieta M. Gozdziak \& Elizabeth A. Collett, "Research on Human Trafficking in North America: A Review of Literature,"103.
} 
in an illicit activity (such as prostitution). If no one is forcing her to engage in such activity, then trafficking does not exist" ${ }^{22}$. From the opposing view, CATW perceived all forms of prostitution as a human rights issue because they believe that prostitution is innately involuntary. Unable to come to a comprehensive definition of trafficking in persons, the UN General Assembly left the discretion for each signatory State to define victims of trafficking, specifically whether to include the issue of consent and whether or not prostitution is legal.

As a signatory to the Palermo Protocol, Canada did not create specific legislation against human trafficking. Instead, Canada, adopted specific offences against human trafficking in the Immigration and Refugee Protection Act (IRPA) and the Canadian Criminal Code (CC). Gaining assent on November 2000, s.118 of the IRPA defines human trafficking as "knowingly organized (through recruitment, transportation, receipt, or harbouring) the entry of an individual into Canada by means of abduction, fraud, deception, or use or threat of force or coercion"23. Implemented on June 2002, s.279 0.1(1) of the CC defines human trafficking as:

"as the recruitment, transportation, concealment, harbouring, or exercising control, direction, or influence over of a person, for the purpose of exploiting them or facilitating their exploitation is guilty of an indictable offence and liable (a) to imprisonment for life if they kidnap, commit an aggravated assault or aggravated sexual assault against, or cause death to, the victim during the commission of the offence; (b) to imprisonment for a term of not more than fourteen years in any other case."24

In general, the scholarly literature views Canada's anti-trafficking policies and laws to be criminally focused rather than taking on a victim's rights approach. The main reason is that many Canadian academics believe s. 118 of the Immigration Refugee Protection Act (IRPA) and s.279 of the $\mathrm{CC}$ to be either too narrow or broad. In Jeffrey and Sullivan's article, "Canadian Sex Work Policy for the 21st Century: Enhancing Rights and Safety, Lessons from Australia," they criticize s.279 of the CC for not recognizing migrants who consent to travel abroad to work in the sex-industry but are then coerced

\footnotetext{
22 Ibid.

${ }^{23}$ Laura Barnett, "Bill C-49 an Act to Amend the Criminal Code (Trafficking in persons) (Rev.ed)," 6.

${ }^{24}$ Ibid, 7.
} 
into sexual exploitation, as victims of trafficking ${ }^{25}$. Trepanier (2003) and Stewart and Gajic-Veljanoski (2005) bring in similar lines of judgment. In the article "Trafficking in Women for Purposes of Sexual Exploitation: A Matter of Consent?", Trepanier argues that s.279 the CC not only rejects the rights of migrant-sex workers, but assumes that prosecutors will not be able to fine convicted traffickers the maximum of \$1 million and life imprisonment ${ }^{26}$. In "Trafficking in Women: The Canadian Perspective", Stewart and Gajic-Veljanoski (2005) blame s. 279 of the CC for criminalizing women who consent to prostitution and illegal smuggling. Migrant-sex workers who consented to be smuggled into Canada to work as prostitutes are labeled as criminal associates rather than victims. As a result, these women are often rejected to apply for refugee status. ${ }^{27}$

Sikka (2009) and Roots (2013) echo the same criticism from a different perspective. In Trafficking of Aboriginal Women and Girls in Canada, Sikka (2013) claims that s.279 of the CC is far too intrusive and disproportionate. An individual can be charged as a trafficker if he or she exerts psychological or emotional control over the movement of a person ${ }^{28}$. This standard is a lot higher than the Palermo Protocol. Roots draw the same connection in "Trafficking or Pimping?: An Analysis of Canada's Human Trafficking Legislation and its Implications". She chastises Canada's legal responses to human trafficking because s.279 of the CC conflates the definition of victims of human trafficking with victims of procurement ${ }^{29}$. From her perspective, s. 279 of the $\mathrm{CC}$ is identical to s.212 (pimping) because both standards require the control or movement of the victim.

\footnotetext{
${ }^{25}$ Leslie Ann Jeffrey \& Barbar Sullivan, "Canadian Sex Work Policy for the 21st Century: Enhancing Rights and Safety, Lessons from Australia," Canadian Political Science Review, no. 3 (2009): 36, accessed July 28, 2014, http://www.cfuw.org/Portals/0/SexWorkersRIghts.pdf.

${ }^{26}$ Monique Trepanier, "Trafficking in Women for Purposes of Sexual Exploitation: A Matter of Consent?," Canadian Women Studies, no. 22 (2003): 54, accessed July 28, 2014, http://search.proquest.com.ezproxy.lib.ryerson.ca/docview/217456914?pq-origsite=summon.

${ }^{27}$ Donna Stewart and Olga Gajic-Veljanoski, "Trafficking in Women: The Canadian Perspective," Canadian Medical Association. Journal, no. 173 (2005): 26, accessed June 12, 2014, http://www.ncbi.nlm.nih.gov/pmc/articles/PMC1167803/pdf/20050705s00018p25.pdf.

${ }_{28}$ Anette Sikkah, Trafficking of Aboriginal Women and Girls in Canada, (Ottawa: Institute on Governance, 2009), 9, http:/site.ebrary.com.ezproxy.lib.ryerson.ca/lib/oculryerson/docDetail.action?docID=10309584.

${ }^{29}$ Katrin Roots, "Trafficking or Pimping?: An Analysis of Canada's Human Trafficking Legislation and its Implications," Canadian Journal of Law and Society, no. 28 (2013): 29, accessed June 12, 2014, http://muse.jhu.edu.ezproxy.lib.ryerson.ca/journals/canadian_journal_of_law_and_society/v028/28.1.roots.pdf.
} 
The U.S. responded differently than Canada. The U.S. adopted an abolitionist approach to prostitution which has a heavy influence in the way Congress structured its trafficking legislation, officially known as Victims of Trafficking and Victims of Severe Forms of Trafficking (TVPA) ${ }^{30}$. The TVPA differentiates victims of trafficking of sex trafficking and victims of severe forms of trafficking. Sex trafficking is severe when the victim is under the age of 18 and or when victim is coerced into involuntary debt bondage and/or slavery. Similar to Canadian authors, the majority of the American literature disagrees with the way the TVPA defines victims of severe trafficking as too narrow and exclusive. As a result, those who are not defined as victims of trafficking are criminalized.

The article "The Challenge of Hidden Slavery: Legal Responses to Forced Labour in the United States”, written in collaboration between Free The Slaves and The Human Rights Centre at the University of California, slams the TVPA for prioritizing the punishment of traffickers and not protecting trafficked victims because T-visas are automatically granted to victims under 15 years of age, while victims older are required to cooperate with law enforcement in order to receive $i^{31}$. Rieger's (2007) article, “Missing the Mark: Why the Trafficking Victims Protection Act Fails to Protect Sex Trafficking Victims in the United States", resonates along similar lines. She vehemently advocates that the TVPA's definition of severe forms of trafficking is discriminatory towards migrant sex-workers, who pay smugglers to bring them into U.S., because it stereotypes them as illegal migrants rather than victims of trafficking ${ }^{32}$. In “The Trafficking Victims Protection Act of 2000: Defining the Problem and Creating a Solution”, Barone raises the issue that consent should not be included in the TVPA ${ }^{33}$. The reason is that it ignores the possibility that traffickers can pose as employers to deceive their victims. Zimmerman (2005) supports Barone's critique in her article "Situating the Ninety-Nine: A Critique of the Trafficking Victims

\footnotetext{
${ }^{30}$ Anja P. Jakobi, Common Goods \& Evil?, 176.

${ }^{31}$ Free the Slaves \& Human Rights Centre, "The Challenge of Hidden Slavery: Legal Responses to Forced Labor in the United States," in Trafficking and The Global Sex Industry 2006, ed. Karen Beeks and Delila Amir (Lanham, MD: Rowman \& Littlefield Publishers, INC., 2006), 124.

${ }^{32}$ April Rieger, "Missing the Mark: Why the Trafficking Victims Protection Act Fails to Protect Sex Trafficking Victims in the United States": 248.

33 Theresa Barone, "The Trafficking Victims Protection Act of 2000: Defining the Problem and Creating a Solution,” Int'l \& Comp. L.J. (2003): 589, accessed July 23, 2014, http://www.heinonline.org.ezproxy.lib.ryerson.ca/HOL/Page?page=579\&handle=hein.journals\%2Ftclj17\&collectio $\mathrm{n}=$ journals\#600.
} 
Protection Act", claiming that TVPA ignores the reality that women are forced into human smuggling and the sex industry because of limited job opportunities in their impoverished environments ${ }^{34}$.

As signatories to the Palermo Protocol, Canada and U.S. had their own discretion to implement anti-trafficking policies and laws to combat human traffickers. Traffickers and smugglers are part of larger criminal enterprises that pose a threat to victims of trafficking, citizens, and their State. The Palermo Protocol and Smuggling Protocol were created to supplement UNTOC ${ }^{35}$.

\section{Structures of Transnational Organized Crime}

The UN General Assembly adopted UNTOC, by a resolution, on November 15, 2000. UNTOC defines transnational organized crime (TOC) as:

"a structured group of three or more persons, existing for a period of time and acting in confer with the aim of committing one or more serious crimes or offences established in accordance with this Convention, in order to obtain, directly or indirectly, a financial or other materiel benefit... an offence is 'transnational' in nature if: (a) it is committee in more than one State; (b) it is committed in one State but a substantial part of its preparation, planning, direction or control takes place within another State; (c) it is committed in one State but involves an organized criminal group that engages in criminal activities in more than one State; or (d) it is committed in one State but has substantial effects in another State"36

Similar to UNTOC's definition, under section 467. (1) of the CC, Canada defines 'criminal organization'

as:

"a group composed of three or more persons in or outside Canada; and, has as one of its main purposes or main activities the facilitation or commission of one or more serious offences, that, if committed, would likely result in the direct or indirect receipt of a material benefit, including a financial benefit, by the group or by any one of the persons who constitute the group",37

As mentioned beforehand, human smuggling and trafficking are criminal operations conducted by TOCs and terrorists groups. There is a great deal of literature discussing what human smuggling and human trafficking is. Human Trafficking and smuggling can occur in any country in the world. However,

\footnotetext{
${ }^{34}$ Yvonne C. Zimmeran, "Situating the Ninety-Nine: A Critique of the Trafficking Victims Protection Act," Journal of Religion \& Abuse, no. 7.3 (2005): 44, accessed 19 July, 2014, 2014.http:/journals2.scholarsportal.info.ezproxy.lib.ryerson.ca/details/15211037/v07i0003/37_stnacottvpa.xml.

${ }^{35}$ Gert Vermuelen, Van Damme, and Wendy De Bondt, Organised Crime Involvement in Trafficking in Persons and Smuggling of Migrant, 12.

${ }^{36}$ Ibid.

37 "What is Organized Crime?," RCMP, last modified October 24, 2011, http://www.rcmp-grc.gc.ca/soc-cgco/whatquoi-eng.htm.
} 
there is strong evidence that focus on particular source countries where trafficking and smuggling is prominent because the lack of effort made by the government and law enforcement. A good portion of the Canadian and American literature emphasizes that Chinese and Russian criminals are involved in human trafficking and or smuggling. However, the issue is that there is no absolute definition of exactly who Chinese and Russian traffickers are. It is important to acknowledge that using the term 'Chinese' and 'Russian' crime groups is simply a catch-all for the many different kinds of ethnic groups in both countries. For example, there are Russian crime groups that are Tartars, Chechens, Armenians, or Ukrainians. As for Chinese crime groups, there are Zhuangs, Huis, Manchus, or Hans. Different Chinese and Russian ethnic groups are recognized when using the terms Chinese and Russian crime groups. Though UNTOC and Canada provide legal definitions of TOCs and criminal organizations, these definitions are unable to clearly identify the criminal structures conducting trafficking and smuggling operations. This is the case for Chinese and Russian criminal syndicates.

There are many types of criminal structures the Chinese and Russians criminals can operate. They can be individual 'entrepreneurs' (individual criminals), local gangs, or highly structured hierarchal criminal organizations such as the Sicilian Mafia. The term mafia originates from the Sicilian mafiosi. This highly structured criminal organization specializes in the "protection business", also known as extortion $^{38}$. For the Chinese, criminal networks can be street gangs, associations (Tongs), or highly structured criminal organizations (Triads) ${ }^{39}$. Street gangs and associations are local in China and internationally based in diaspora ethnic enclaves. Triads, on the other hand, are centralized in Hong Kong. Though these Chinese criminal groups are involved in human trafficking and smuggling at different levels (i.e., conducting the entire operation or simply used to collect fees), it is unknown which criminal structure has monopolized the two clandestine operations.

In his book Human Smuggling Organizations, Zhang claims that smuggling operations are dependent on the market, and are therefore unstable and sporadic. Due to the unreliable market, only

\footnotetext{
${ }^{38}$ James O. Finckenauer and Elin J. Waring, Russian Mafia in America (Boston: Northeastern University Press, 1998), 142.

${ }^{39}$ Sheldon Zhang, Human Smuggling Organization, 157-160.
} 
Snakeheads are involved in this business ${ }^{40}$. Snakeheads are small groups of loosely connected criminals that conduct smuggling operations if the opportunity arises. This group of criminals are not part of Chinese Street gangs, Tongs, and or Triads. Zhang's stance conflicts with several authors. In the book Russian and Chinese Trafficking: A Comparative Perspective, Shelley describes smugglers as part of criminal organizations that are very similar to traditional crime groups (street gangs, Tongs, or Triads) ${ }^{41}$. This is based on the history of Snakeheads, who originated from the Chinese triads based in Hong Kong, Macao, and Taiwan. In Understanding Organized Crime, Mallory claims that though drug trafficking is the primary criminal activity that Chinese Street gangs, Tongs, and Triads are involved in, but all groups have also moved into human smuggling ${ }^{42}$. Chin, in "The Social Organization of Chinese Human Smuggling”, takes it further, stating that Chinese triads are dominating the smuggling business ${ }^{43}$. In addition to human smuggling, Chinese criminal groups are involved in human trafficking. Makarenko, in Organized Crime or Crimes Organized?, classifies Chinese traffickers as Triads or small groups of individuals connected to other criminal organizations such as the Triads, Albanian organized crime, or the Japanese Yakuza ${ }^{44}$. Chinese traffickers that belong to a highly structured organization are also involved in the trafficking of narcotics and arms. In Russian and Chinese Trafficking: A Comparative Perspective, Shelley demonstrates that Chinese traffickers operating in Europe are small diaspora groups that are linked back to a head leader in China ${ }^{45}$.

Russian smugglers and traffickers have been labeled as a mafia or loosely connected networks. Several authors, including Finckenauer and Waring (1998), Mallory (2012), and Vermuelen (2010), contend that Russian criminal groups do not reflect the traditional characteristic of a mafia such as the Sicilian mafia. In Russian Mafia in America, Finckenaur and Waring stress that there is no evidence that

\footnotetext{
${ }^{40}$ Ibid.

${ }^{41}$ Louise Shelley, "Russian and Chinese Trafficking: A Comparative Perspective," 71.

${ }^{42}$ Stephen Mallory, Understanding Organized Crime (Mississauga: Jones \& Bartlett, 2012), 169.

${ }^{43}$ Ko-Lin Chin, "The Social Organization of Chinese Human Smuggling," in Global Human Smuggling, ed. David Kyle and Rey Koslowski (Baltimore, Maryland: The Johns Hopkins University Press, 2011), 191.

${ }^{44}$ Tamara Makarenko, "Organized Crime or Crimes Organized?," in Human Trafficking and Human Security, ed. Anna Jonsson (New York: Routledge, 2009), 43.

${ }^{45}$ Louise Shelley, "Russian and Chinese Trafficking: A Comparative Perspective," 71.
} 
Russian organized crime represent a mafia-type structure due to the lack of hierarchical organization, continuity, and loyalty towards one particular group ${ }^{46}$. Vermuelen in Organized Crime Involvement in Trafficking in Persons and Smuggling of Migrants, stands firmly by the notion that the majority of hierarchal criminal groups, including the Russians, are now replaced with loosely connected groups that make up only a certain function of the entire operation ${ }^{47}$. In Understanding Organized Crime, Mallory echoes the same line of thought of Ficnkenaur, Waring, and Vermuelen, claiming that Russian criminal networks do not resemble structures of the Sicilian Mafia or Japanese Yakuza because their organizational structure is neither centralized nor controlled by a small group of elite leaders ${ }^{48}$. Although these authors contend that Russian traffickers and smugglers are not part of the Russian Mafia, other authors such as Zhang and Shelley argue differently.

In Human Smuggling Organizations, Zhang postulates that the trafficking of women across national borders, especially from Russia to Western countries, cannot be conducted by small groups or individual entrepreneurs ${ }^{49}$. The reason the level of sophistication and resources required to conduct international human trafficking. This means that mainly highly organized Russian criminal organizations are conducting these operations. Furthermore, highly organized Russian crime groups not only engage in human trafficking operations, but also many other nefarious activities such as drug and arms trafficking, money laundering, and the forging of documents. Shelley complements Zhang's allegations in Russian and Chinese Trafficking as she argues that since the early 1990s, larger Russian criminal organizations have become the dominant players in transnational human trafficking ${ }^{50}$.

As demonstrated in Canadian and American scholarly literature on the topic, there is no clear definition for Chinese and Russian criminal networks involved in human trafficking and smuggling. It is also unclear if anyone has monopolized the two trades. Although there is no absolute answer, Finckenauer

\footnotetext{
46 James O. Finckenauer and Elin J. Waring, Russian Mafia in, 142.

${ }^{47}$ Gert Vermuelen, Van Damme, and Wendy De Bondt, Organised Crime Involvement in Trafficking in Persons and Smuggling of Migrants, 39 \& 43.

${ }^{48}$ Stephen Mallory, Understanding Organized Crime, 92-94.

49 Sheldon Zhang, Human Smuggling Organization, 178 \& 180.

${ }^{50}$ Louise Shelley, "Russian and Chinese Trafficking: A Comparative Perspective," 71.
} 
offers three reasons why it is important for scholars and experts to discern the prominent players in human trafficking and smuggling operations ${ }^{51}$. Having a clear definition enables experts and practitioners to comprehend the phenomenon, helps law enforcement and intelligence agencies to develop adequate countermeasures, and guide policy makers in developing anti-trafficking policies that target the proper criminal structures. Unfortunately, the reality is that it is nearly impossible to come to an agreement because human trafficking and smuggling are clandestine in nature. Whether traffickers and smugglers are individuals, loose criminal networks, mafia-like, or highly-structured criminal organizations, they are nonetheless transnational criminal syndicates that operate their illicit operations for the purpose of profit making. Complicating the issue today is the fact that criminals are now working in conjunction with terrorist groups. This brings human trafficking and human smuggling to a higher caliber of criminality, which requires States to be better equipped.

\section{Nacro-Terrorism and The Crime-Terror Nexus}

Some TOCs that operate human trafficking rings are beginning to work in alliance with wellknown blacklisted terrorist groups ${ }^{52}$. Officially known as 'Narco-Terrorism' and the 'Crime-Terror Nexus,' these two phenomena refer to the relationship between TOCs and terrorist groups. NarcoTerrorism occurs when TOCs and terrorist groups form alliances in the drug trade. The Crime-Terror Nexus moves beyond partnerships in the drug trade and includes other criminal activities. Multiple partnerships create a higher opportunity for both groups to converge into one identity and/or switch ideologies. Before Narco-Terrorism and the Crime-Terror Nexus, these two groups were identified as two separate entities that played two very different games, yet still posed an inherent threat to human security and State security.

\footnotetext{
${ }^{51}$ James O. Finckenauer and Elin J. Waring, Russian Mafia in America, 308-309.

52 Peng Wang, "The Crime-Terror Nexus: Transformation, Alliances, Convergence," Asian Social Science 6, no. 6 (2010): 15, accessed July 28, 2014, http:search.proquest.com.ezproxy.lib.ryerson.ca/docview/822929729/fulltextPDFaccountid=13631.
} 
The primary goals of the TOC are to make money, gain power, and monopolize its trade ${ }^{53}$. Thus, TOCs smuggle people, transport narcotics, guns, ammunition, and illicit goods, and traffic people across borders for the sole purpose of profit making. In contrast, terrorist groups are people that use extreme violence to accomplish their political, ideological, and/or religious goals. This means that fines and criminal punishments are ineffective deterrence towards these people. Terrorists can be state-sponsored or non-state actors. They act through extreme violence, which comes at the costs of innocent civilian lives. Terrorism can be local, nationwide, or transnational. Since $9 / 11$, the war on terror has shifted its battleground to Western countries. This is especially the case for Canada and the U.S.. In the wake of 9/11, U.S. blamed Canada to be a security threat because of its porous borders and weak immigration and refugee system. Though none of the 19 hijackers entered U.S. through Canada, the focus now, for both countries, is homeland security against terrorist groups such as Al-Qaeda ${ }^{54}$.

The Crime-Terror nexus is the link and even convergence between TOCs and terrorist groups. In other words, TOCs' and terrorist groups' visions, structures, and methods of operations may change due to the interaction of the other group. Jennifer Hesterman, a retired U.S. Colonel, who specializes in the field of the crime-terror nexus, proposes the theory of Generation Warfare, which explains the evolution of combat and warfare ${ }^{55}$. First-generation warfare was characterized by battles between nation-states through swords, shields, bows and arrows, and spears. The First World War introduced the secondgeneration warfare mainly defined by trench warfare. The theory of Generation Warfare has now moved into the fifth-generation warfare where partnerships and motivations between TOCs and terrorist groups are beginning to converge. This type of warfare is asymmetrical as both groups use conventional and unconventional means (military tactics and weapons) to achieve their economic, political, religious, and/or social cause.

\footnotetext{
${ }^{53}$ Stephen Mallory, Understanding Organized Crime, 258.

${ }^{54}$ Peter Andreas, "The Mexicanization of the US-Canada Border," International Journal 60, no. 2 (2005): 453-455, accessed July 28, 2014, http://www.jstor.org.ezproxy.lib.ryerson.ca/stable/10.2307/40204302?origin=api.

55 Jennifer L. Hesterman, The Terrorist-Criminal Nexus (New York: Taylor \& Francis Group, 2013 ), 273.
} 
According to the fifth-generation warfare, TOCs and terrorist groups are more open to partnerships. This generation resembles Makarenko's theory of Crime-Terror Continuum emphasizing that a TOC and terrorist group can adopt and even replicate one another's structures. They can even adopt each other's ideologies depending on the socio-economic and political environment they are situated in ${ }^{56}$. Each stage brings TOCs and terrorist groups closer to one another until they have completely converged. There are three main pillars: alliances, operations, and convergence.

Alliances between TOCs and terrorist groups are opportunistic isolated events. Both groups may simply be seeking a one-time expertise consultation in money laundering, bomb-developments, or counterfeiting, or a one-time support in their illicit activities, such as accessing smuggling routes to move terrorists across borders. For example, both Al-Qaeda and the Liberation Tigers of Tamil Eelam (LTTE) are known to work with TOCs. In the 1990s, terrorist groups began to develop in-house criminal activities because they wanted to avoid issues of business partnerships with TOCs (i.e. differences in motivation, strategies, and ethnicity). Some of the main terrorist groups mutated into organizations that could carry out criminals and terrorist activities. Terrorist organizations such as Fuerzas Armadas Revolucionaries de Colombia (FARC), the Basque Homeland and Freedom Movement (ETA), and the Kurdistan Workers' Party (PKK) were engaged not only in the trafficking of narcotics, but human smuggling as well ${ }^{57}$.

Convergence is the third pillar when TOCs and terrorist groups transforms into a single entity. Terrorist groups, in this case, no longer conduct illicit activities for political, ideological, or religious causes, but simply for profit making. For example, the Palestine Liberation Organization (PLO) is formally recognized as a radical terrorist group. However, since the 1970s it has become successful in criminal and business activities. The top high-ranking officers of the PLO have essentially shifted their ideological vision to more economic goals. This in effect alters the mindsets of their followers, as one member shares:

\footnotetext{
56 Tamera Makarenko, "The Crime-Terror Continuum: Tracing the Interplay between Transnational Organized Crime and Terrorism," Routledge Taylor \& Francis Group 6, no. 1 (2004): 103, accessed July 28, 2014, http://journals2.scholarsportal.info.ezproxy.lib.ryerson.ca/pdf/17440572/v06i0001/129_tccttibtocat.xml. ${ }^{57}$ Ibid.,131 \& 134-135.
} 
"Initially I was of the view (the leader) were doing Jihad, but now I believe it is a business and people earning wealth through it. I thought (the leaders) were true Muslims, but now I believe they are a fraud, they are selling Islam as a product... first I was there for Jihad, now I am there for my financial reasons.",58

Ironically, the organization transformed into a legitimate Palestinian political party operating in the West Bank. It was granted UN observer status in 1974, and was thus recognized as a legitimate entity representing the Palestinian people ${ }^{59}$. In November 1988, Chairman Yasser Arafat publically announced that PLO condemned all forms of terrorism. Five years later, the Olso Accords established the PLO as the "Palestinian Authority, with self-government" over the West Bank. However, it lost the Palestinian elections in 2006 to its rival party, Hamas, an organization labelled as terrorist by the U.S. and European Union $^{60}$. The PLO regained authority in the West Bank when the Hamas government was dismissed in 2007. Up to today, the Hamas still exercises de facto rule over the Gaza strip.

Hesterman's theory on Generational Warfare and Makarenko's Crime-Terror Continuum theory can be concretely analyzed with some of the main TOCs and terrorist groups today. Narco-Terrorism was solidified during the 1970s and 1980s, specifically in Latin America ${ }^{\mathbf{6 1}}$. Narco-Terrorism is slightly different from the Crime-Terror nexus. It was, and still is, a phenomenon where terrorist groups (i.e. Revolutionary Armed Forces of Columbia) engage in partnership with the drug cartels (i.e. La Cosa Nostra) in drug manufacturing and trafficking for the purpose of funding their terrorist activities.

The Crime-Terror nexus progresses after Narco-Terrorism where terrorist groups and TOCs engage in many other criminal activities. This relationship came into existence after the collapse of the Soviet Union and now has become a lot more common after 9/11. The result of the Cold War created political instability in Eastern Europe and the former Soviet Union, and a massive stockpile of guns,

\footnotetext{
${ }^{58}$ Lyubov Grigorova Mincheva and Ted Robert Gurr, Crime-Terror Alliance and the State: Ethnonationalist and Islamist Challenges to Regional Security (New York; Routledge Taylor \& Francis Group, 2013), 144.

59 "Creation, Aims, Methods \& Effectiveness of the Palestinian Liberation Organization (PLO) 1964-1974," Israel \& Judaism Studies.au, accessed September 6, 2004, http://www.ijs.org.au/The-Palestine-LiberationOrganisation/default.aspx.

${ }^{60}$ Zachary Laub, "Hamas," Council on Foreign Relations, last modified August 1, 2014, http://www.cfr.org/israel/hamas/p8968.

${ }^{61}$ Peng Wang, "The Crime-Terror Nexus: Transformation, Alliance, Convergence," 15.
} 
ammunition, and weaponry ${ }^{62}$. The partnership between the two groups substantially grew after 9/11 due to the U.S. interdiction against terrorist groups' financial systems. The UN developed the UN Security Council Resolution and International Convention for the Suppression of the Financing of Terrorism ${ }^{63}$. This gave the U.S. and signatory States the authority to freeze terrorist accounts by shutting down their financial links in banks, charity organizations, mosques, and shell companies. Terrorist groups in response switched to criminal activities to fund their causes. The most common criminal activities both groups have been conducting in partnership include human smuggling, human trafficking, bribery, the trafficking of illicit commodities (i.e. fraudulent documents and or drugs), and money laundering.

The Crime-Terror Nexus and Narco-Terrorism are mostly prominent Latin America, the U.S., and Canada. There are several terrorist groups that clearly has been cooperating with TOCs in North America. This includes Hezbollah and Al-Qaeda, both of which are becoming involved in human trafficking or human smuggling. Hezbollah is an Islamist terrorist group that has killed many innocent civilians in different States. Prior to 9/11, this group was responsible for the murder of over 400 U.S. military personnel in the bombing of the Marine barracks in Beirut, Lebanon in 1983 and the 1996 Khobar Towers bombing in Saudi Arabia ${ }^{64}$. Hezbollah has shared military tactics and trafficking routes with other major terrorist groups such as Al-Qaeda and FARC. This terrorist group is successfully operating in the U.S., Canada, and Latin America. In Canada, Hezbollah has been operating their money laundering schemes, trafficking drugs, and smuggling illegal migrants across the U.S.-Canadian borders. As for Latin America, Hezbollah focuses mainly in drug trafficking in the intersection of borders between Paraguay, Brazil, and Argentina. In the U.S., Hezbollah has been sharing underground pipelines for drug and human trafficking $^{65}$.

Terrorist groups have heavily influenced American gangs. According to the 2011 National Gang Threat Assessment report, local American Street gangs are moving into non-traditional criminal activities

\footnotetext{
${ }^{62}$ Stephen Mallory, Understanding Organized Crime, 264.

${ }^{63}$ Peng Wang, "The Crime-Terror Nexus: Transformation, Alliance, Convergence," 12.

${ }^{64}$ Jennifer L. Hesterman, The Terrorist-Criminal Nexus, 75-76.

${ }^{65}$ Stephen Mallory, Understanding Organized Crime, 258 \& 264.
} 
such as human trafficking ${ }^{66}$. According to Hesterman, MS-13 is the deadliest threat in the U.S. after $A l$ Qaeda. There are about 10,000 members operating up to 42 states. In 2005, FBI director Robert Mueller declared this gang as the highest priority in his criminal enterprise department. Originating in El Salvador, but formed in the U.S., many of the members were former government death squads or served as former guerrilla members with the Farabundo Marti National Liberation Front. The gang has extensive expertise in military tactics and is well known for its extreme violence, especially in their mercilessness and barbaric murders of children and pregnant mothers. Recently, MS-13 has moved into human trafficking and the gun trade. Furthermore, MS-13 leaders have also been reported in meeting with U.S. citizen and the FBI's most-wanted Al-Qaeda member, Adnan El Shukrijunba. This is a deadly combination as MS-13 is currently controlled by Mexico's largest drug cartel, the Los Zetas.

Los Zetas were former fighters for the Grupo Aeromóvil de Fuerzas Especiales (GAFE), the elite special forces in Mexico's special forces corps ${ }^{67}$. These individuals were specially trained in counterterrorism and counterinsurgency to fight the war against drugs and capture key officials in Mexico's drug cartels. With an estimated 2,000 members, Los Zetas is now the largest drug cartel in Mexico. It competes violently with other drug cartels for territory. According to Former Head of Drug Enforcement Agency's El Paso Intelligence Centre, Highway I-35 is the prized jewel for Mexican drug cartels. I-35 is the third longest North-South highway the stretches from Laredo, Texas, all the way to Duluth, Minnesota, which is near the Canadian border at Thunder Bay. Due to Los Zeta's power, they have been able to control and influence MS-13, other Mexican Mafia, and Texas syndicates to conduct their human trafficking and human smuggling operations. Los Zetas has also been training and equipping MS-13 with sophisticated weapons such as AR-15s, M-16s, and AK-47s. Based on the meeting between MS-13 leaders and Adnan El Shukrijunba, it would not be a surprise for Al-Qaeda to cooperate with Los Zetas in human trafficking, human smuggling, and drug trafficking. This is certainly a major fear for law enforcement and intelligence communities in North America.

\footnotetext{
${ }^{66}$ Jennifer L. Hesterman, The Terrorist-Criminal Nexus, 123.

${ }^{67}$ Ibid., 142.
} 
The Crime-Terror Nexus and Narco-Terrorism are growing in North America. Both focus on drug trafficking, human trafficking, money laundering, and human smuggling. The manufacturing and consumption rate of drugs, particularly cannabis and amphetamine-type stimulants (i.e. ecstasy, methamphetamine, and amphetamine) has not decreased between 2008 and 2013. According to United Nations Office on Drugs and Crime (UNODC), the global leader in the fight against illegal drugs and international crime, one of the main reasons there is no decrease in the rate of producing and consuming drugs is that there has been a shift where the drugs are being manufactured ${ }^{68}$. Production and supply routes have shifted from developed countries to developing countries where there is a lack of strong government and law enforcement stability. This further attracts TOCs and terrorist groups into these countries. For example, FARC, Hezbollah, Al-Qaeda, and Mexican drug cartels have been identified operating in Mali and Guinea-Bissau.

According to Hesterman, human trafficking ranks as the second most lucrative criminal activity after drug trafficking. A U.S. State Department 2012 report estimated an increase of 15 million victims trafficked compared to 12 million victims in 2005. Victims of trafficking have also been forced to become drug mules when transported from a source country to a destination country. This method is a lot safer for criminals as they do not need to be physically present during the operation. Operation Black Leaves, carried out by the Italy's military police and Europol in 2009, is a good illustration. Women trafficked for the purpose of sexual exploitation were forced to carry drugs from Madrid to the Italian regions of Piemonte and Marche ${ }^{69}$. This method is also used for smuggling operations. Albanian TOCs have been smuggling both people and drugs across the Adriatic sea. With the emergence of Narco-Terrorism and the Crime-Terror Nexus, there may be a potential that TOCs and terrorist groups are also using this type of scheme.

\footnotetext{
${ }^{68}$ Ibid., 33-35.

${ }^{69}$ Gert Vermuelen, Van Damme, and Wendy De Bondt, Organised Crime Involvement in Trafficking in Persons and Smuggling of Migrants, 61.
} 


\section{Issues in Collecting Data on Trafficked Victims}

Human trafficking and smuggling are, of course, clandestine in nature. TOCs and terrorist groups have their practices in operating these illicit activities. Both groups intentionally hide victims of trafficking and smuggled migrants from the general public, law enforcement and intelligence agencies. They also change their methods according to the socio-economic and political environment. These factors make it difficult for law enforcement, intelligence agencies, and NGOs to collect data that fully capture the entire picture of the two criminal operations. Consequently, agencies' reports on the number of trafficked victims per year are often inconsistent. For example, in 2003, the U.S. Government Accountability Office estimated that 14,5000 to 17,500 victims were trafficked into the country. However, the International Organization for Migration (IOM) estimates that approximately 900 victims were trafficked into U.S. from 2001 to $2005^{70}$. There are at least two other major issues that contribute to these inconsistent results. First, there is no legal consensual agreement as to who is a trafficked victim. The second issue is that data collection and prioritization are not uniform.

The Palermo Protocol lays out the basic foundation of what constitutes a victim of trafficking, yet it does not have the authority to replace State provisions. This gives signatory and ratified States a significant amount of discretion to decide how to craft and implement anti-trafficking policies and laws that reflect their conception of trafficking and smuggling ${ }^{71}$. The U.S. and Canada, for example, crafted their own definitions of what constitutes trafficking and trafficked victims, and neither definition fully agrees with the other. Aside from defining human trafficking, the U.S. also developed Trafficking In Persons (TIP) reports as part of its mandate written in the 2000 Victims of Trafficking and Violence Prevention Act. The U.S. yearly releases TIP reports on each country's efforts in combating human trafficking. Each country's interdiction efforts are based on four factors. Firstly, there should be antitrafficking laws and policies that prohibit severe forms of trafficking and punish traffickers. Secondly, the

\footnotetext{
${ }^{70}$ Anja P. Jakobi, Common Goods \& Evil?, 178.

${ }^{71}$ Gert Vermuelen, Van Damme, and Wendy De Bondt, Organised Crime Involvement in Trafficking in Persons and Smuggling of Migrants, 36.
} 
government recognizes that sex trafficking is a grave crime. Thirdly, the criminal punishment should adequately deter traffickers. Lastly, the government should make serious efforts to eliminate severe forms of trafficking ${ }^{72}$.

Based on these four standards, each country is ranked into three tiers. Tier 1 signifies full compliance, Tier 2 means the country is making significant effort, and Tier 2 Watch List represents seminoncompliance and at risk of falling into Tier 3, which is no compliance. When a country is ranked Tier 3, the U.S. will economically sanction the country by limiting or barring any type of trade of humanitarian aid and cultural and educational exchange programs until the country makes significant progress to push itself up to Tier 2 or Tier 2 Watch List. Collecting data and publishing TIP reports goes beyond the requirements of the Palermo Protocol. The U.S. evaluates countries with its own definition on human trafficking and severe forms of trafficking. This is an issue since not all countries, including Canada, define human trafficking as U.S. does. Consequently, a U.S. TIP report does not entirely or accurately reflect another country's report on the number of victims trafficked.

In addition to these differences, States themselves have difficulty in grasping the issue of human trafficking and smuggling. NGOs, law enforcement agencies, and intelligence agencies may have their own interpretation of who the victim of trafficking is. These groups have different mandates and obligations. Different mandates, objectives, and working definitions amongst agencies leads to different methods of collecting information. This leads not only to difficulty in integrating the data from different sources $^{73}$, but as well the ability for agencies to agree with one another's findings. It is also important to acknowledge that NGOs (including advocacy groups for victims of trafficking) and governments have different images to uphold. NGOs may exaggerate the actual number of victims trafficked for fundraising and advocacy purposes. Government agencies, on the other hand, may report lower numbers of

\footnotetext{
${ }^{72}$ Anja P. Jakobi, Common Goods \& Evil?, 176.

${ }^{73}$ Guri Tyldum and Anette Bruonovskis, "Methodological Challenges in Research with Trafficked Persons: Tales from the Field," in Data and Research on Human Trafficking A Global Survey 2005, ed. by Frank Laczko and Elzbieta Gozdziak, (Geneva: International Organization for Migration, 2005), 24.
} 
victims trafficked to indicate that their interdiction against human trafficking is effective and swift ${ }^{74}$. Inconsistent definitions also lead to methodological issues in terms of collecting data. For example, the U.S. counts all undocumented migrants crossing the border as trafficked victims ${ }^{75}$. Canada faces some of these issues as well.

Prior to the adoption of s.279 of the CC, the Royal Canadian Mounted Police (RCMP) in 2004 reported that about 800 to 1,200 people were trafficked into and within Canada. However, since the implementation of s.279, the RCMP has withdrawn its estimation, acknowledging the difficulty in identifying the numbers. Yet, West Coast Leaf, an NGO in British Columbia that focuses on empowering women, reports that as high as 15,000 victims are trafficked into and within Canada on an annual basis ${ }^{76}$. The legal definition of who is a trafficked victim is another issue. The Canadian Government has difficulty in distinguishing who is a victim of trafficking. Though s.118 of the IRPA and s.279 of the CC lay out the provision of human trafficking, there is no agreed definition among policy makers in the Interdepartmental Working Group on Trafficking in Persons (IWG-TIP) ${ }^{77}$. IWG-TIP is the unit that is responsible for developing public policies in relation to human trafficking in Canada. Members within the group acknowledge that there is no guiding legal framework to identify victims of trafficking. The Canadian Government also faces systemic issues in terms of collecting information on the number of people trafficked into the country. The reason is that its combines trafficking people with illegal migrants, which also includes people smuggled and refugee claimants. Compounding the issue is that victims of trafficking are often stigmatized to be illegal migrants if they have consented to prostitution. Shame, guilt,

\footnotetext{
${ }^{74}$ Gert Vermuelen, Van Damme, and Wendy De Bondt, Organised Crime Involvement in Trafficking in Persons and Smuggling of Migrants, 35.

${ }^{75}$ Elzbieta M. Gozdziak \& Elizabeth A. Collett, "Research on Human Trafficking in North America: A Review of Literature," 107.

${ }^{76}$ Nicole A. Barrett, An Exploration of Promising Practices in Responses to Human Trafficking in Canada (Vancouver: International Centre for Criminal Law Reform and Criminal Justice Policy, 2010), http://site.ebrary.com.ezproxy.lib.ryerson.ca/lib/oculryerson/docDetail.action?docID=0434242.

${ }^{77}$ Elzbieta M. Gozdziak \& Elizabeth A. Collett, "Research on Human Trafficking in North America: A Review of Literature," 105.
} 
mistrust, and fear of condemnation often hinder the victims from seeking help from law enforcement or $\mathrm{NGOs}^{78}$.

Another issue with data collection is evaluating methodological approaches on how experts arrive at their opinion. Researchers and key informants base their information on certain groups that often do not encompass the entire trafficked population. For example, according to the IOM Mission in Ukraine, victims of trafficking, specifically women, approach rehabilitation centres months or years after returning to their country of origin ${ }^{79}$. This is problematic for data collection purposes. IOM states that victims of trafficking who knew they were going to work in the sex industry are unlikely to identify themselves to NGOs and rehabilitation centres.

The Crime-Terror Nexus and Narco-Terrorism further complicates data collection on human trafficking and smuggling. The convergence between human trafficking, human smuggling, and narcotic trafficking operations is becoming prominent in North America. This has a substantial impact on the way Canadian, American, and Latin American intelligence agencies, law enforcement agencies, and NGOs conduct their research. Since research on human trafficking and smuggling is already difficult to conduct, it is questionable whether or not relying on migration theories provide a better explanation of the two changing phenomenon.

\section{Migration Theories and Human Trafficking and Smuggling}

There are many theories that attempt to explain transnational migration. Some theories examine transnational migration on a macro-level, while others utilize a micro-level analysis. Neoclassical economic theory hypothesizes that the growth of technology and international trade weakens the sovereignty and autonomy of States to control their borders, and that this in effect encourages criminals to

\footnotetext{
${ }^{78}$ Guri Tyldum and Anette Bruonovskis, "Methodological Challenges in Research with Trafficked Persons: Tales from the Field." 26.

${ }^{79}$ Ibid., 25.
} 
exploit weak immigration border systems ${ }^{80}$. International trade also comes at the cost of attracting an abundance of people from the Global South to work in the Global North due to better economic opportunities. However, if migrants do not have the adequate credentials or patience to legally migrate, many turn to clandestine means.

World Systems Theory, Micro-economic Theory, and Dual Market Theory focus transnational migration on a micro-level. The World Systems Theory hypothesis is that citizens in developing countries lack employment opportunities ${ }^{81}$. These people are attracted to migrate into developed countries such as North America, Western Europe, and Oceania because they offer more employment opportunities. This theory is similar to Micro-Economic Theory which views transnational migration to be mainly influenced by push factors that limit employment opportunities in an impoverished environment. Dual Market Theory, on the contrary, argues that transnational migration occurs mainly due to Western countries' attractiveness of employment and better life (pull factors). These countries heavily depend on cheap labor from undeveloped countries because local citizens do not want to work in low-paid harsh working conditions.

Theories on transnational migration cannot fully explain why there is human trafficking or human smuggling. It is unreliable to depend on these theories because they often contradict one another and their generalization ignores many other factors. As discussed earlier, the Crime-Terror Nexus is drastically changing the relationship between human trafficking, human smuggling, and the trafficking of illicit commodities. The second factor is corruption, which is the largest expenditure for TOCs and terrorist groups. Bribing can be for the purpose of proactively aiding the traffickers or turning a blind eye $\mathrm{e}^{82}$. Political factors are a catalyst for human trafficking. A country that has limited or no political stability can become a safe haven for TOCs and terrorist groups. Limited political stability often occurs when there is a political transition, especially from a socialist system to capitalist system, where there is an absence of

\footnotetext{
${ }^{80}$ Alexis A. Aronowitz, Human Trafficking, Human Misery: The Global Trade in Human Beings (London: Praeger, 2009), 25.

${ }^{81}$ Sheldon Zhang, Human Smuggling Organization, 16.

${ }^{82}$ Alexis A. Aronowitz, Human Trafficking, Human Misery: The Global Trade in Human Beings, 62.
} 
government control around land borders, where they are regional conflicts, natural disasters, or an absence of political will for the government to serve its citizens ${ }^{83}$. Socio-cultural factors also fuel human trafficking in certain parts of the world. The issue of discrimination towards minority groups, gender, and children encourage human trafficking. Child marriage, for instance, is a prominent traditional practice in some Asian cultures. Another example is life-threatening diseases such as HIV/AIDS, which has increased the trafficking of children in two major ways. Traffickers and clients are attracted to children because they are usually disease free due to their young age. Children are trafficked at a higher rate because they are 'worn out' at a quicker rate. HIV/AIDS has also forced impoverished families to sell their children to traffickers in order to survive ${ }^{84}$. As demonstrated, there are many factors that influence human trafficking; however, the mechanics of the operations remain the same.

\section{The Mechanics of Human Trafficking Operations}

Human trafficking can be broken down into several stages of operations. This includes recruitment, obtaining necessary documents (legitimate or fraudulent), corruption, transportation into a destination country, coercion, exploitation, and money laundering. Before discussing the logistics of trafficking operations, it is important to understand the demographics of trafficked victims. There are certain minority groups and individuals that are more likely to be trafficked due to their vulnerability and the demand from clients. Men are often trafficked into forced labor (i.e. construction and or military forces) than they are forced to face sexual exploitation ${ }^{85}$. On the other hand, women and children are more likely to be trafficked into sexual exploitation and forced labor (i.e. domestic servitude, prostitution, child pornography, or adult pornography $)^{86}$. The types of forced labor and sexual exploitation depend on where women and children come from. For example, child victims in Southeastern Europe are trafficked into

\footnotetext{
${ }^{83}$ Louise Shelley, "Russian and Chinese Trafficking: A Comparative Perspective," in Human Traffic and Transnational Crime: Eurasian and American Perspectives, 142-146.

${ }^{84}$ Ibid.

${ }^{85}$ Ana Repetskaia, "Classifying the Elements of Human Trafficking Crimes," in Human Traffic and Transnational Crime 2005, 51.

${ }^{86}$ Anja P. Jakobi, Common Goods \& Evil?, 161.
} 
begging and crime, whereas child victims in Central and South America and North America are trafficked into sexual exploitation, crime, and agricultural work ${ }^{87}$. In the Canadian case, Asian victims are often trafficked into Vancouver and western regions of Canada, and Latin American and Eastern European victims are trafficked into Toronto and Eastern regions; all of which are trafficked mainly into the sex industry ${ }^{88}$.

Once traffickers have set their eyes on their prey, recruitment begins. Recruitment of victims can be conducted by kidnapping or deceiving victims. Deceiving victims into the trafficking is more common than kidnapping due to its cost-effectiveness ${ }^{89}$. Traffickers may employ the 'lover-boy method,' but often instead use newspaper advertisement because this method yields a larger pool of potential victims. Advertisements can include events for photography shoots or beauty pageant competitions, marriage agencies, travel and employment opportunities, and/or open announcements in hiring girls for escort services in another country. The 'lover-boy method' is a deceptive method for organized crime use. A young man poses as an innocent caring and loving individual to attract a young woman, preferably in need finically ${ }^{90}$. Once she has fallen in love with him, he slowly induces her into prostitution for 'his sake'. Sometimes, these criminals would also introduce drugs to their victims in order to keep them physically and mentally dependent ${ }^{91}$. The lover-boy method is a deceptive method, but not as quick and effective compared to false advertisements.

\footnotetext{
${ }^{87}$ Alexis A. Aronowitz, Human Trafficking, Human Misery The Global Trade in Human Beings, 41.

${ }^{88}$ Ibid., 100.

${ }^{89}$ Saltanat Sulaimanova, "Trafficking in Women from the Former Soviet Union for the Purposes of Sexual Exploitation," in Trafficking and The Global Sex Industry, ed. Karen Beeks and Delila Amir (Lanham, MD: Rowman \& Littlefield Publishers, Inc., 2006), 65.

${ }^{90}$ Gert Vermuelen, Van Damme, and Wendy De Bondt, "Organised Crime Involvement in Trafficking in Persons and Smuggling of Migrants", 70.

91 Annemarie Tocher, "Domestic Trafficking in Aboriginal Persons: The Legacy of Colonization and Sexual Exploitation," The HindSight Group, n.a. (2012): 22-23, accessed July 28, 2014, http://www.firstpeoplesgroup.com/mnsiurban/PDF/reports/Tocher_A-Legacy_of_Colonization_and_Sexual _Exploitation_(2012).pdf.
} 
Fake events are well thought out recruitment techniques. Women are often deceived into joining an out of the country pageant tour ${ }^{\mathbf{2}}$. Similar to fake events, there are also fake marriage agencies, commonly known as mail order brides. Traffickers set up the victim with a husband (client) in another country. A woman in this scenario can become a victim of trafficking in several manners. She may be deceived to believe that she is marrying a foreign man when in fact she will be sexually exploited by him, or a woman may consent to the marriage in order to obtain eligibility for spousal sponsorship, but is sexually exploited upon arrival. Victims of mail order brides are usually from Asia (China, Philippines, Thailand, and Vietnam), Eastern Europe, the Commonwealth of Independent States (Russia), and Latin America (Brazil, Columbia, and Costa Rica). Clients are often from Canada, the U.S., Japan, and Europe (mainly from Germany, Norway, and Sweden) ${ }^{93}$. The mail order bride business is legal in Canada, but in order for brides to be eligible for spousal sponsorship, they must be married and live with her husband for a minimum of two years ${ }^{94}$.

Travel and employment agencies are a very popular recruiting method for Russian and Chinese traffickers. Shell companies are set up with fake advertisements, contact information, and agents to offer employment abroad. Fake job postings in waitressing, modeling, strip dancing, and secretarial work are commonly used ${ }^{95}$. Sometimes traffickers pose as escort service agents and openly advertise for sex work abroad $^{96}$. Advertisements include a good monthly salary, free travel, and accommodations. Employees in this case may or may not be aware that prostitution is illegal in the destination country.

Women recruiters are becoming a popular method for traffickers. IOM's Counter-Trafficking Module data obtained information in 78 countries from 1999 to $2006^{97}$. The results indicated that $42 \%$ of

\footnotetext{
${ }^{92}$ Liudmila Erokhina, "Trafficking in Women in the Russian Far East: A Real or Imaginary Phenomenon?," in Human Traffic and Transnational Crime: Eurasian and American Perspectives 2005, ed. Sally Stoecker and Louise Shelley (Lanham, MD: Rowman \& Littlefield Publishers, Inc., 2005), 82.

${ }_{93}$ Alexis A. Aronowitz, Human Trafficking, Human Misery: The Global Trade in Human Beings, 122-123.

${ }^{94}$ The Canadian Press, "New Canadian Immigration Rules Target Marriage Fraud," Huffingtonpost, last modified October 26, 2014, http://www.huffingtonpost.ca/2012/10/26/new-canadian-immigration-rules-marriagefraud_n_2022401.html\#slide=1688084.

${ }^{95}$ Saltanat Sulaimanova, "Trafficking in Women from the Former Soviet Union for the Purposes of Sexual Exploitation,” 64.

${ }^{96}$ Ibid., 84.

${ }^{97}$ Alexis A. Aronowitz, Human Trafficking, Human Misery: The Global Trade in Human Beings, 54.
} 
the 9,646 sex recruiters were women. This does not include another $6 \%$ where men and women worked together to recruit their victims. During the recruitment phase, there are three main approaches traffickers manipulate women ${ }^{98}$. Women may unknowingly ask their friends to join in their venture in working abroad. Traffickers may send their victims back to their country of origin and threaten them to recruit their friends and family. Lastly, women knowingly recruit victims to buy their freedom or have become part of the trafficking ring. The third approach is also known as 'happy trafficking.' Women knowingly pretend that they had a wonderful and prosperous experience working abroad to attract more women. This type of scheme is not exclusive to a particular ethnic group. Women from the Russian Federation, Bulgaria, and Romania have been arrested in the Netherlands as traffickers. In Nigeria, older women, a Maman or Madam, recruit women between the ages of 15 and 25 to be sexually exploited in the Netherlands. The Dutch National Rapporteur on Trafficking in Human Beings (an independent monitoring agency of Netherlands' efforts to combat human trafficking) reports Mamans and Madams on average are in the mid-40s who used to be victims of trafficking. They have paid off their debt and in turn work for their traffickers to make a living.

After obtaining the proper documents and bribing officials, traffickers transport their commodities to the destination country. There are many ways to transport victims of trafficking across borders, depending on the distance and security the destination country. For countries that are closer to the country of origin, crossing the border by land may be the most appropriate. As for destination countries across continents, tour guide agencies, ship containers, or commercial air flights are required ${ }^{99}$. Coercion is the tactic traffickers use to force their victims into sexual exploitation or forced labor. It can be applied prior to transportation, but is definitely enforced in the destination country. Physical and psychological coercion are often employed hand-in-hand. In order to quickly instill obedience, traffickers will severely beat those who disobey, withdraw food and water, or slip drugs into their victim's food and

\footnotetext{
${ }^{98}$ Ibid., 53.

${ }^{99}$ Anja P. Jakobi, Common Goods \& Evil?, 161.
} 
drinks $^{100}$. On top of physical abuse and substance inducement, traffickers also can financially coerce their victims through debt bondage. Many traffickers pay a fraction of what victims earn, and then quickly dock their 'pay-check' to pay off their travel costs, housing, food, fines for disobedience, and expenses to work as prostitutes. Paying victims is a form of bribery traffickers use to keep their victims silent. This blurs the lines for law enforcement to distinguish between a victim of trafficking and a person being smuggled who decided to engage in prostitution on her accord ${ }^{101}$. In terms of psychological coercion, traffickers often threaten to report victims as illegal migrants to law enforcement or threaten to harm their family members. There was one case in the UK where a trafficking group forced a young Czech mother into prostitution by threatening to force her adolescent into child pornography.

Sexual exploitation is an illegal activity that can operate in illegal and legal industries. Victims of trafficking can be forced to work in sex industries that may be legally permitted in the destination country ${ }^{102}$. Forced prostitution is the most common in countries that ban prostitution. However, there are other sexual exploitations such as working in the porn industry, military prostitution, sex tourism, or surrogate mothers. Traffickers force victims to have a child in the country of origin and give birth to the infant in the destination country to make the adoption process a lot quicker. This method was reported in the 1997 Rossiiskaia Gazeta in an article titled "Motherhood for Sale." Surrogate mothers from Hungary were transported to the United States and Canada to give birth. These babies were sold to American and Canadian clients ${ }^{103}$. The stages of trafficking operations mentioned above, from recruitment to sexual exploitation through physical and psychological coercion, can be exemplified in Canada's experience with the Strippergate scandal in 2004.

From 1998 to 2004, Canada granted a special visa for foreign exotic dancers, many of whom were victims of trafficking from Russia and Eastern Europe. To understand how this scandal came to be, it is important to understand the socio-economic and political factors Canada and Russia were

\footnotetext{
${ }^{100}$ Ana Repetskaia, "Classifying the Elements of Human Trafficking Crimes," 52.

${ }_{101}$ Alexis A. Aronowitz, Human Trafficking, Human Misery: The Global Trade in Human Beings, 58.

${ }^{102}$ Louise Shelley, "Russian and Chinese Trafficking: A Comparative Perspective," 55.

${ }^{103}$ Ibid., 57.
} 
experiencing prior to the scandal. The changes in the stripping industry in Canada and Russia's political and economic shifts created the opportunity for Russian traffickers. Russia's history and its relations to human trafficking will first be discussed. This provides valuable context for the Strippergate scandal.

Russia has undergone several major socio-economic and political events over the course of the $20^{\text {th }}$ and $21^{\text {st }}$ centuries. These factors, as a result, have created a trafficking culture that can persist today. In the 1920s and 1930s, Russia experienced a violent combination of the Volga famine, communist revolution, civil war, and the New Economic Policy ${ }^{104}$. These crises left close to seven million homeless and unemployed, mainly single mothers and their children. Women lost their jobs in the textile factories and other light industries due to the privatization process influenced by the New Economic Policy. As a result, young women and girls resorted to prostitution in order to eat, and run-away children were forced by criminals to transport heroin in their stomachs from Central Asia to Moscow. Unsupervised children and teenagers also were targets of trafficking. They were recruited through drug addiction by the suppliers. Citizens of the Soviet Union who had jobs were not much better off compared to the homeless. According to UN's Human Development Report in 2004, fifty-three percent of the Russian population lived under U.S. \$4 a day ${ }^{105}$.

In addition to poverty and economic instability, corruption in the public and private sector provided easier access for traffickers to conduct their operations. Until the 1980s, the Communist Party was in control of the Soviet Union, and the majority of members had close relationships with the black market controlled by a leader known as the Vory V. Zakone ("thief-in-law") ${ }^{106}$. He was the Russian "Robin Hood" for the local peasants. Lenin and Stalin tried to condemn his group by sending them into the gulags (Soviet slave labor camps). It was in gulags that Vory V. Zakone developed his criminal organization by recruiting more members in the prison and began forging relationships with corrupt government officials. After the Second World War, four core types of criminals networks emerged: the

\footnotetext{
${ }^{104}$ Sally Stoecker, "Human Trafficking: A New Challenges for Russia and the United States," 16.

${ }^{105}$ Saltanat Sulaimanova, "Trafficking in Women from the Former Soviet Union for the Purposes of Sexual Exploitation," 62.

${ }^{106}$ Stephen Mallory, Understanding Organized Crime, 90-91.
} 
Russian criminal elite (Vory V. Zacone), the nomenklatura (corrupt Communist officials and business leaders), ethnic groups (i.e. Chechens, Armenians, and Georgians), and regional criminal groups. The size of these groups put together had an enormous reach into the Russia's economy. The Center for Strategic and International Studies on Russian Organized Crime in 1997 reported that more than 50\% of the country's banks, $40 \%$ of private business, and $60 \%$ of state-owned enterprises were controlled by organized crime ${ }^{107}$. This scope of corruption did not just occur after the break of the Soviet Union but has accumulated since the end of the Second World War.

The breakup of the Soviet Union in 1991 exacerbated the rate of human trafficking due to the division of States and the collapse of the social system. The breakup created 15 separate States, visa-free entry policies, and the loss of centralized control by Moscow ${ }^{108}$. States were given the autonomy to craft their migration laws and regulations. Some contradicted the federal laws. The decentralization of the Russian Federation left several borders undefended. The Georgian transit route, for example, was expanded due to an open-border policy with Turkey. As a result, more women and children are trafficked through Georgia to Turkey and Greece and on to the destination countries.

Another wave of unemployment quickly rose as Russia was transitioning from a communist regime to a market economy. The transition not only cut millions of public sector jobs, but also public sector services, primarily social and healthcare systems, which funded all levels of education, medical services, and day care for children. In a short span of five years, between 1990 and 1995, United Nations Children's Fund (UNICEF) reported that women lost five million jobs while men lost two million jobs in the Russian Federation ${ }^{109}$. Over $97 \%$ of these women were well-educated, and $94 \%$ were lone parents. Many women resulted to prostituting on the streets in order to provide food on the table. The lack of employment and lack of political will for the government to support their citizens pushed many women to seek work abroad. For example, IOM’s 2000 survey of trafficking victims in Kyrgyzstan commented " $79 \%$ of the respondents said that unemployment drove them to look for work abroad. The main reason

\footnotetext{
${ }^{107}$ Ibid.

${ }^{108}$ Sally Stoecker, "Human Trafficking: A New Challenges for Russia and the United States," 21.

${ }^{109}$ Ibid., 15.
} 
they were working as commercial sex workers abroad were said to be related to their lack of money and hopes for a better future."110

Several influential factors throughout Russia's history have created an opportunity for the human trafficking culture to persist today. Poverty and economic instability throughout the 1920s up to the breakup of the Soviet Union continuously adds more citizens into the massive pool of vulnerable population. Though poverty is not uncommon in other developing countries, Russia is a unique country because corruption is heavily intertwined in the public and private sector. Its porous borders also give criminal groups the upper hand to move commodities in and out of the country. These factors continuously fuel the human trafficking culture in Russia. As a result, Russian traffickers can thrive in their business and extend its operations into North American countries such as Canada. This is the case in Strippergate scandal as Russian traffickers trafficked their victims into Canada, for the purpose of forced labor and sexual exploitation, during changes in the stripping industry.

Canada's stripping industry was undergoing several major changes in the early 1990s. Table dancing was introduced which increased the opportunity for strippers to make more tips. This influenced club owners to cut daily wages, enforce bar fees, and extend shift hours from six to eight hours ${ }^{111}$. Strip club owners offered more employment opportunities as freelancing, lap dancing, and VIP rooms (individually confined rooms where strippers strip exclusively for a client) were also introduced. Though lap dancing is illegal, it still exists due to its lucrative profit ${ }^{112}$. Many house girls decided to become freelancers in response. House girls are strippers that work for one club and are regularly scheduled to work in undesirable hours (i.e. $12 \mathrm{pm}-5 \mathrm{pm})^{113}$. Freelancers, on the other hand, work on their own time

\footnotetext{
${ }^{110}$ Saltanat Sulaimanova, "Trafficking in Women from the Former Soviet Union for the Purposes of Sexual Exploitation," 63.

${ }^{111}$ Diane Eleanor Meaghan, "The Political Economy of Stripping: The Social Construction of Sex Trade Work," University of Toronto (Canada), no. NQ53864 (2000): 163, accessed July 27, 2014, http://ezproxy.lib.ryerson.ca/login?url=http://search.proquest.com/docview/304660687? accountid=13631.

${ }^{112}$ Audrey Macklin, "Dancing Across Borders: 'Exotic Dancers,' Trafficking, and Canadian Immigration Policy," International Migration Review 37, no. 2 (2003): 46, accessed July 27, 2014. http://journals2.scholarsportal.info.ezproxy.lib.ryerson.ca/details/01979183/v37i0002/464_dabdtacip.xml.

${ }^{113}$ Tuulia Law, "Cashing in on Cachet?: Ethnicity and Gender in the Strip Club," Canadian Journal of Women and the Law 24, no.1 (2012): 46, accessed July 27, 2014, http://muse.jhu.edu.ezproxy.lib.ryerson.ca/journals/canadian_journal_of_women_and_the_law/v024/24.1.law.html.
} 
schedules, and if popular, are often asked to work during peak hours (9pm-2am) ${ }^{114}$. Lap dancing and freelancing became advantageous for strippers due to how lucrative and flexible their schedules are, but this came at the cost for strip club owners. The massive shift from house girls to freelancers meant a loss of consistent house girls covering undesirable shifts ${ }^{115}$. In response, many strip club owners in Toronto and Eastern cities in Canada began requesting foreign nationals from Human Resource Development Canada (HRDC). They asserted that local Canadians were not interested in working in the strip club industry when in fact there were simply not enough house girls. In response, HRDC conducted a blanket Labor Market Opinion (LMO) and found that foreign exotic dancers would not put Canadian women out of work. ${ }^{116}$

Prior to 1997, E-99 was enforced between Canada and the U.S. Based on s.20 (5)(2)(iii) and s.22 of the Immigration Regulations, E-99 waives HRDC from conducting a job validation and Labor Market Opinion (LMO) for American strippers obtaining work permit in Canada ${ }^{117}$. In 1997, HRDC revoked E99 breaking the informal exotic dancer program between Canada and the U.S. ${ }^{118}$. The revocation allowed foreign nationals from abroad to apply and work in Canada as foreign exotic dancers. Though this required HRDC to validate job and perform LMOs on a case-by-case basis, it was exempted for foreign exotic dancers. In 1998, HRDC issued a generic letter eliminating mandatory requirement due to its "difficulty of performing an LMO per case and assumption that it would not adversely affect the employment opportunities of Canadian citizens" ${ }^{\text {"119 }}$. Within the same year, then HRDC Minister Pierre Pettigrew implemented a special category for 'exotic dancers' in the National Occupational Classification

\footnotetext{
${ }^{114}$ Suzanne Bouclin, "Exploited Employers or Exploited Entrepreneurial Agents? A Look at Erotic Dancers," Canadian Women Studies 23, no. 3 (2004): 133, accessed July 27, 2014, http://ezproxy.lib.ryerson.ca/login?url=http://search.proquest.com/docview/217457085?accountid=13631.

${ }^{115}$ Tuulia Law, "Cashing in on Cachet?: Ethnicity and Gender in the Strip Club," 144.

${ }^{116}$ Donna M. Hughes, "The Demand for Victims of Sex Trafficking?," In L. McDonald (Ed.),Toronto: Status of Women Canada. n.a. (2005): 42, accessed July 27, 2014, http://www.uri.edu/artsci/wms/hughes/demand_for_victims.pdf.

${ }_{117}$ Audrey Macklin, "Dancing Across Borders: 'Exotic Dancers,' Trafficking, and Canadian Immigration Policy," 45.

${ }^{118}$ Lynn McDonald, Brooke More, and Natalya Timoshikina, "Migrant Sex Workers from Eastern Europe and the Former Soviet Union: The Canadian Case," Status of Women Canada, no. SW21-63 (2000): 7, accessed July 27, 2014, http://publications.gc.ca/collections/ Collection/SW21-63-2000E.pdf.

${ }^{119}$ Ibid., 47.
} 
List. As a result, foreign nationals were granted the exotic dancers visas, so long as they proved they were strippers and had a job offer in Canada ${ }^{120}$. It was estimated that 500 foreign exotic dancers annually applied for this visa, the majority from Eastern Europe and Russia. Many of the foreign exotic dancers coming into Canada with a temporary work permit were trafficked for the purpose of sexual exploitation. This will be further discussed below.

This visa for foreign exotic dancers came to an end in 2004 after a high level political scandal was exposed. The Opposition discovered that Alina Balaican, a Romanian exotic dancer, entered into Canada with the special work permit, but worked for Immigration Minister Judy Sgro's re-election campaign. Furthermore, the administration helped Alina extend her visa. ${ }^{121}$ In 2003 alone, Canada's Department of Citizenship and Immigration (CIC) granted 661 temporary work visa for young women to work as foreign exotic dancers, $80 \%$ of whom Romanian. The scandal was linked to organized crime. A senior government official anonymously reported that Human Resources Minister Joe Volpe was battling with his own senior officials in ending the program. The government official stated:

"There was a lot of concern because they are afraid of these guys. They are afraid of the guys that bring in the strippers because they are not nice guys. Nobody seems to know how it for approved. When we [Mr. Vople] pressed them on it...the best answer [we] got is that they wanted to get their people out of dealing with these characters, these guys. I'm not saying all club owners are bad guys. But some of them are organized crime. A guy walks into your office and says, 'Look, you know I'd like you to facilitate this and if you don't you are going to start having problems with your car or whatever.' Are you going to call the cops? What are you going to do? The cops are going to come and say, 'Do you have any witnesses?' and they'll say, 'Well, if he does anything let us know and we'll come back.",122

The victims in the Strippergate scandal were either fully or partially deceived into human trafficking. Fully deceived women were those who were unaware of working as strippers in Canada. They were deceived to believe that they were working in occupations such as professional modeling and

\footnotetext{
${ }^{120}$ Donna M. Hughes, “The Demand for Victims of Sex Trafficking?," 51.

121 Ibid., 43.

122 “Organized crime intimidated bureaucrats, inside official says," National Post, last modified December 18, 2004, http://www.canada.com/national/nationalpost/news/story.html?id=158bc48e-c6cd-4a49-927b-

$5 \mathrm{f} 60 \mathrm{c} 3 \mathrm{cbb} 092 \&$ page $=2$.
} 
secretary work $^{123}$. This was accomplished by spreading rumors in remote villages. Traffickers posed as agents looking for employees to work abroad. Partially-deceived women, on the contrary, were aware that they would work as strippers in Canada, however they did not know they would be exploited. In this case, traffickers openly advertised that they were recruiting women for escort services.

Many of the foreign exotic strippers who received temporary work visas from CIC were from Eastern Europe and Russia. These victims were forced into labor (stripping) and sexual exploitation. There were several deceptive methods club owners enforced to control the movements and interactions of their victims. The most popular practice was to seize their visas and passports ${ }^{124}$. They would then enforce combinations of psychological and physical coercions, including threatening victims that they would hand them over to law enforcement in order to be deported, or lie that they were frequently under surveillance by men employed by club owners. Owners also intentionally isolated their victims from their Canadian co-workers for two reasons. Firstly, this kept victims out of reach for help and, secondly, isolation created economic competition between both groups as victims often performed sexual services due to coercion and debt bondage ${ }^{125}$. Scheduling was another means to control the movement of victims. Club owners forced their victims to work longer hours to prohibit free time ${ }^{126}$. Those who refused to strip or perform sexual services were threatened by employers to harm their families in their home country or they would be physically and sexually assaulted by their employers. One Hungarian victim commented:

"The first, second, third, fourth night I didn't work at all. I said: "There is no way I going to dance. You can do anything with me. I'm not going to dance." On Sunday night he said: "OK, you've been here for one week...you didn't make any money, and we are going to teach you how to make money...he sent four guys in my room so he could teach me how I have to make money. They raped me for four days and four nights." 127

\footnotetext{
${ }^{123}$ Lynn McDonald, Brooke More, and Natalya Timoshikina, "Migrant Sex Workers from Eastern Europe and the Former Soviet Union: The Canadian Case," 44.

${ }^{124}$ Maja Muftic, "The Impact of Restrictive Immigration Policies on Human Trafficking in Canada," University of Ottawa, no. MR61284 (2009): 77, accessed July 28, 2014, http://ezproxy.lib.ryerson.ca/login?url=http://search.proquest.com/docview/520201637?accountid=13631.

${ }^{125}$ Audrey Macklin, "Dancing Across Borders: 'Exotic Dancers,' Trafficking, and Canadian Immigration Policy," 472.

${ }^{126}$ Lynn McDonald, Brooke More, and Natalya Timoshikina, "Migrant Sex Workers from Eastern Europe and the Former Soviet Union: The Canadian Case," 46.

${ }^{127}$ Ibid., 54.
} 
Debt bondage was used by employers to ensure that victims would not have the financial means to escape. Employers would lie to their victims that they were keeping their money for safekeeping, or that they were remitting their earnings for the families. Another method was to continuously charge victims fees for transportation, being late, the opportunity to work, and living accommodations ${ }^{128}$.

The constant physical and psychological micromanagement of employers directly perpetrated psychological and physical damage towards their victims. One particular trauma these victims faced was known as "stripper damage, ${ }^{129}$. Each patron has his/her sexual fetish(es) that the victims had to pose and provide at the cost of suppressing their feelings and values. Being coerced into constantly reconstructing and performing multiple characteristics for financial gain created a 'permanent shell-shocked looked...the inability to de-dramatize." ${ }^{130}$ The Strippergate scandal indicates Canada's vulnerability to TOCs and terrorist groups, particularly with its immigration system. Yet, there are many other 'vulnerabilities' in Canada that TOCs and terrorist groups can abuse to conduct their illicit operations.

\section{Immigration and Threats to National Security}

Land-border crossings, underground tunnels, boats, and commercial air flights are not uncommon routes TOCs and terrorist groups use. Commercial air flights and land-border crossings are unique methods as both require visas and passports. In order to successfully gain access, without the detection of authorities, TOCs and terrorist groups use proper or fraudulent documents ${ }^{131}$. TOCs and terrorist groups have the liberty to consistently change the way they conduct their clandestine operations. They have no legal restrictions. Consequently, the destination countries, including Canada, are consistently fighting an upstream battle against TOCs and terrorist groups. In the case for Canada, new developments from TOCs or terrorist groups, whether for human trafficking, human smuggling, or the trafficking of illegal

\footnotetext{
${ }^{128}$ Audrey Macklin, 'Dancing Across Borders: 'Exotic Dancers,' Trafficking, and Canadian Immigration Policy," 472 .

${ }^{129}$ Curtis Fogel and Andrea Quinlan, "Dancing Naked: Precarious Labour in the Contemporary Female Strip Trade," Canadian Social Science 7, no. 5 (2011): 54, accessed July 28, 2014,

http://ezproxy.lib.ryerson.ca/login?url=http://search.proquest.com/docview/1221242443?accountid=13631.

${ }^{130}$ Ibid., 54.

${ }^{131}$ Raimo Väyrynen, "Illegal Immigration, Human Trafficking, and Organized Crime," 1-2.
} 
commodities, nonetheless have the same goal: to infiltrate Canadian borders and the immigration and refugee system. TOCs and terrorist groups can exploit Canada's immigration and refugee determination system in order to conduct their clandestine activities. It is nearly impossible to determine the exact number of criminals and terrorists that come into Canada through these two systems. Some illegally enter Canada and pose as refugee claimants. It would be dangerous to turn a blind eye to the possibility that criminals and terrorists, such as MS-13, Al-Qaeda, and/or LTTE, use this method. They are people that use whatever means necessary to achieve their ideological goals.

Canada's immigration, refugee, security, and law enforcement systems face multiple issues in defending its citizens, victims of trafficking, and sovereignty. There is an array of recommendations offered by Canadian experts in the national security and immigration field. These approaches aim to protect victims of trafficking, refugees, and the Canadian public by strengthening border security and the immigration and refugee systems. It is unlikely that these approaches will be implemented due to political pressures from some political parties, lawyers, NGOs, academics, and the media. The majority of the general Canadian public is unaware that TOCs and terrorist groups intend to gain access into Canada through its refugee determination and immigration systems. They are porous processes that unfortunately can enable criminals and terrorists to by-pass the detection of the Canadian authorities. Consequently, some criminals and terrorist enter Canada posing as refugee claimants. While criminals or terrorists are waiting for their hearing, they are able to freely roam in Canada to conduct their clandestine operations. Prominent cases such the Golden Venture in 1999, Ahmed Ressam, and Manickavsagam Suresh indicate the manipulation of Canada's refugee determination system by TOCs and terrorist groups. Before discussing each case in further detail, it is important to understand the mechanics of Canada's immigration and refugee determination system, and the internal issues it faces.

Canada faces three major systemic issues when it comes to protecting Canadian citizens, victims of trafficking, and combating TOCs and terrorist groups. These issues are the multiple legal restrictions set out by the refugee judicial system, limited use of detention and inability to maximize the Safe Third Country Agreement (STCA), and the internal structure of the Canadian Border Service Agency (CBSA) 
at Toronto's Lester Pearson International Airport. Canada's refugee judicial system operates within the guidelines of the UN Refugee Convention. The Convention defines a 'refugee' as a person who:

“...owing to well-founded fear of being persecuted for reasons of race, religion, nationality, membership of a particular social group or political opinion, is outside the country of his nationality and is unable or, owing to such fear, is unwilling to avail himself of the protection of that country; or who, not having a nationality and being outside the country of his former habitual residence as a result of such events, is unable or, owing to such fear, is unwilling to return to it."132

A UN Convention refugee is an individual persecuted on the grounds of race, religion, nationality, and or membership in a particular group ${ }^{133}$. There is, however, an important difference between a refugee and a refugee claimant ${ }^{134}$. Under the premise of both international and Canadian law, a refugee applies for refugee status in resettlement camps outside of Canada. Since there are not enough resettlement programs to accommodate the number of individuals applying, there is a queue in the system here in Canada.

Individuals wait until a Canadian official can process and approve their application. A refugee claimant, on the contrary, has the legal right to claim refugee status in Canada. S/he may genuinely be fleeing from danger and enter Canada through illegal means, or s/he may illegally enter Canada and pretend to be in danger. The latter, posing as a refugee claimant, generally enters into Canada under false pretenses, with fraudulent documents, and through the same networks TOCs and terrorist groups transport their victims or clients into Canada. While in Canada, a refugee claimant is not recognized as a refugee until his or her application is approved.

Canada signed the Refugee Convention and its Protocol in 1967. There are three-core obligations the country needs to abide by ${ }^{135}$. Under the principle of non-refoulement, Canada is prohibited from repatriating a refugee claimant unless it is demonstrated that the individual is a threat to national security and public safety. Secondly, refugee claimants are entitled to legal protection and judicial process under

\footnotetext{
${ }^{132}$ Udara Jayasinghe and Sasha Baglay, "Protecting Victims of Human Trafficking within a 'Non-refoulement' framework: Is Complementary Protection an Effective Alternative in Canada and Australia?," International Journal of Refugee Law 23, no. 3 (2011): 494, accessed July 29, 2014, http://journals2.scholarsportal.info.ezproxy.lib.ryerson.ca/pdf/09538186/v23i0003/489_pvohtweaicaa.xml.

${ }^{133}$ Paul Weis, "The Refugee Convention, 1951," UNHCR, n.a, http://www.unhcr.org/4ca34be29.html.

${ }^{134}$ Scott D. Watson, The Securitization of Humanitarian Migration: Digging Moats and Sinking Boats (New York: Routledge, 2009), 40-41.

${ }^{135}$ Ibid., 44, 46 \& 48.
} 
Articles 32 and 16 of the Refugee Convention. Lastly, arbitrary detentions are prohibited unless for the purpose of verifying the identity of the claimant, especially when documents are fraudulent or have been destroyed, and to protect national security and its citizens. Population wise, Canada is currently the top 6 th country in the world that attracts the most amount of refugee claimants ${ }^{136}$. There are many refugee and refugee claimants worldwide due to unstable social, economic, and political conditions in many failed or failing states, often known as 'refugee producing countries'. According to The United Nations Refugee Agency (UNHCR) 2012 refugee statistics report, there are 32,643 refugee claimants pending to be processed in Canada. This is compared to 18,966 refugee claimants pending in the U.S. Though refugees and refugee claimants are legally different, some refugee claimants are genuinely fleeing from persecution on one of the five grounds. They have the right to apply for refugee status in Canada, but many enter the country through illegal means. Unfortunately, there are also refugee claimants that do not fit into the definition of the UN Convention of a refugee, but pose as one. This complicates the issue for front-line immigration officers since a refugee claimant can either be genuine or bogus.

"Bogus refugees" is a politically laden term popular with the current Conservative government. Some people, including many academics, human rights advocates, and opposing political parties, dislike this term because it makes 'bogus' synonymous with 'refugees.' They further argue that the current government recklessly uses this term. However, the reality is that refugee claimants, bogus or genuine, enter Canada illegally if they are not government or privately sponsored. Bogus refugees in particular are jurisdiction shoppers that are not truly persecuted. They make up stories and provide fraudulent documents. Canada is a target country for bogus refugees. Family reunion is one of the main reasons why more than half of refugee claims are made inland by claimants who came into Canada with a visitor's visa $^{137}$. Another attraction is free legal assistance and the eligibility to work while awaiting the Immigration Refugee Board (IRB). Many people pose as refugees because they do not have an adequate

\footnotetext{
136 “UNHCR 2012 Refugee Statistics: Full Data,” The Guardian. June 19, 2013, http://www.theguardian.com/news/datablog/2013/jun/19/refugees-unhcr-statistics-data?commentpage=1. ${ }^{137}$ Stephen Gallagher, "Canada's Broken Refugee Policy System," in Immigration Policy and Terrorist Threat in Canada and the United States, ed. Alexander Moens and Martin Collacott (Toronto: Fraser Institute, 2008 ), 60.
} 
education, credentials, or professional skills to legally enter into Canada. Up to 2009, Canada has received approximately 37,000 refugee claimants, 13,000 of which crossed over the U.S. border. Many of these individuals applied for refugee status months or even years after they have landed in Canada. Though these individuals do not have legitimate claims, they may desperately want to avoid their countries of origin due to other dangerous reasons that are not recognized under the definition of the UN Convention Refugee. These people who escape their country of origins and enter illegally into destination countries, such as Canada, are vulnerable to traffickers who pose as smugglers. Even if the smugglers did successfully transport their clients into Canada, they are nonetheless criminal syndicates that conduct their smuggling operations for profit and not for any type of humanitarian cause. This poses a threat to Canada's refugee system.

Canada's refugee system is divided into two core components: the Immigration Refugee Board (IRB) and the Refugee Appeal Division (RAD). The purpose of the IRB is to determine whether a refugee claimant should be recognized as UN convention refugee. The decision is based upon an appointed panel member. This system is inherently problematic as it produces inconsistent decisions, is open to abuse, and is administratively slow ${ }^{138}$. For example, panel members are politically appointed, and therefore often act on their own political and ideological values ${ }^{139}$. This was evident in 2000 when all resettlement countries put together accepted 500 refugees from Pakistan and Sri Lanka while Canada received 1,600 from Pakistan and 2,000 from Sri Lanka. For the Sri Lankan case, many Tamils have been fleeing the country since the 1980 s due to persecution by the country's ethnic majority, the Sinhalese ${ }^{140}$. The high acceptance of Tamil refugee claimants from Sri Lankan created an enormous Tamil community in Canada. Unfortunately, terrorist groups such as the LTTE posed as refugee claimants to gain access into Canada. LTTE is a terrorist group that aims to create an independent state in Sri Lanka through extreme violence

\footnotetext{
138 Ibid.

139 Arne Kislenko, "Guarding the Border: Intelligence and Law Enforcement in Canada's Immigration System," in Oxford Handbook of National Security Intelligence 2010, ed. Loch K. Johnson (Toronto: Oxford University Press, $2010), 322$.

${ }^{140}$ Bhattacharji Preeti, "Liberation Tigers of Tamil Ealam (aka Tamil Tigers) (Sri Lanka, Separatists)," Council on Foreign Relations, last modified May 20, 2009, http://www.cfr.org/separatist-terrorism/liberation-tigers-tamileelam-aka-tamil-tigers-sri-lanka-separatists/p9242.
} 
including land mines, suicide bombings, murders, ethnic cleansing, kidnapping, and the forced conscription of child soldiers $^{141}$. In 2001, Toronto authorities initiated Project 1050 arresting 51 individuals formally associated with LTTE for extortion, gun trafficking, drug and human smuggling, and murder against other rival gang members ${ }^{142}$. Majority of these individuals entered Canada as refugee claimants. Two years later after Project 1050, only ten were convicted and two amongst the group were deported. The lack of testimonies by the Tamil communities was due to their fear of this terrorist group. It is unknown exactly how many LTTE members and Muslims extremists entered Canada from Pakistan and Sri Lankan as refugee claimants in 2000. However, based on Project 1050, it is reasonable to speculate that there is a connection between terrorist groups posing as refugee claimants. Despite the fear of this connection, it is more difficult for panel members to reject a refugee claim than to approve one. The reason is that negative decisions require legal justification for potential RAD hearings, whereas positive decisions, in the past, did not. Moreover, the majority of panel members have experience in the immigration legal field, but no front line-experience. Credibility is often determined by evaluating how forms are filled and the technicalities in claimants' testimonies, rather than in-depth evaluation by a panel member. Scheduling is also another issue as all parties need to work with the same schedule. This includes the panel member, both counselors, the claimant, and an interpreter if needed. Such a deadly combination results in little to no negative decisions. No other country in the world uses a system like the IRB. Australia, France, the UK, and the U.S. use first instance determination led by public officials to remove refugee claimants that arrive with no legitimate claim ${ }^{143}$. Many Canadian humanitarians, immigration advocates, and lawyers romanticize the IRB system because they perceive it to ensure procedural safeguards for claimants and independence from the influence by the acting government ${ }^{144}$.

\footnotetext{
${ }^{141}$ Stewart Bell, Cold Terror, (Canada: John Wiley \& Sons Canada, Ltd.), 77-85.

142 Arne Kislenko, "Guarding the Border: Intelligence and Law Enforcement in Canada’s Immigration System," 323.

${ }^{143}$ Stephen Gallagher, “Canada's Broken Refugee Policy System,” 61.

${ }^{144}$ Ibid., 63.
} 
The Refugee Appeal Division (RAD) is another issue. Claimants who go negative before the IRB are given another chance to appeal their case. Bill C-11, proposed in 2001, was designed to allocate more resources for aiding genuine refugees overseas by preventing abuse from bogus refugees, criminals, and terrorists $^{145}$. The Canadian Bar Association, Amnesty International, and the Canadian Council of Refugees quickly denounced the bill claiming it to be too draconian. The bill was eventually passed, but with the creation of RAD as a compromise. RAD permits failed refugee claimants to return to Canada and apply for a 'risk assessment' determination to avoid immediate and permanent remove.

Canada is seen by some to be "strong-armed" into giving bogus refugees the right to a hearing due the landmark case to Singh vs. Minister of Employment and Immigration in $1985^{146}$. The case involved seven applicants, six of which associated with Akali Dal Party, a Sikh organization fighting for the independence of the Punjab from India. All entered Canada illegally, claimed refugee status, and in the end the Supreme Court of Canada ruled that anyone physically in Canada is entitled to the protection under the Canadian Charter of Rights and Freedoms. This decision in effect not only grants every refugee claimant the right to a hearing, but also attracts more bogus refugees, thereby unintentionally provides more business for TOCs and terrorist groups. Some refugee lawyers and advocacy groups for refugees justify that based on Singh's case, Canadian law ensures that every refugee claimant has the right to a fair process and hearing. This creates an unintended opportunity for TOCs to use the Canadian law and its refugee system as their advantage to conduct their trafficking and smuggling operations. This is the case in the Golden Venture in 1999 when a total of 599 migrants were smuggled onto the shores of British Columbia by boats from Fujian, China. One refugee lawyer for the claimants comments in the media.

"According to our laws, a person has the right to make a refugee claim after arriving in Canada-regardless of how they get here. To come to Canada and make a refugee claim is not illegal. That is not an illegal refugee claimant...they make their refugee claims after arriving in Canada in accordance with Canadian law. They're not jumping queues, but following a set process for persons who claim to have a fear of persecution." ${ }^{147}$

\footnotetext{
${ }^{145}$ Ibid., 321.

146 Arne Kislenko, "Guarding the Border: Intelligence and Law Enforcement in Canada's Immigration System,” 324 $\& 325$.

${ }^{147}$ Alison Mountz, Seeking Asylum: Human Smuggling and Bureaucracy and the Border (Minneapolis: University of Minnesota Press, 2010), 105.
} 
The Chinese claimants were given a refugee hearing date, yet 500 of them did not show up. Chinese criminal organizations transported all 500 to New York's Chinatown to work.

In addition to TOCs, some fear that Canada's refugee determination system can be easily manipulated by terrorist organizations. Terrorist groups have on several occasions also exploited the refugee system by posing as refugee claimants. Aside from Project 1051, there are at least two other prominent cases. Officially known as the Millennium bomber, Algerian Al-Qeada member Ahmed Ressam was caught attempting to blow up the Los Angeles International airport during the millennium celebration $^{148}$. He failed to enter the U.S. from Canada at the Port Angeles crossing in Washington. The U.S. customs officer suspected him of possessing narcotics but instead found materials for a bomb in his vehicle. It was soon discovered that Ressam entered Canada illegally and claimed refugee status, but never appeared at his refugee hearing.

The second example is Manickavasagam Suresh. This case exemplifies Canada's porous refugee system as a target for terrorist groups to infiltrate. Suresh was the former Canadian head of the LTTE. Suresh was sent by LTTE in Sri Lanka to lead the Canadian LTTE community in 1990. He was a refugee claimant hoping to gain status in Canada. While waiting, he took over the leadership of the World Tamil Movement (WTM), a Toronto-based LTTE front to fund the Tamils' terrorist activities in Sri Lanka. On October 18, 1995, Suresh was arrested for being an active member of LTTE. While in Don Jail, Suresh continued his leadership by sharing a telephone transfer system with Mansour Ahani, a secret agent for the Iranian foreign assignation branch. In response, the Federation of Associations of Canadian Tamil (FACT) orchestrated demonstrations (850 people outside the House of Commons), political lobbying, and administrated public letters portraying themselves and Suresh as a liberation army protecting their Tamil constituents from the Sri Lankan government. They also glamorized Suresh to be a community activist and a human rights worker, arguing that he would be tortured and killed if he were to be deported to Sri Lanka.

\footnotetext{
${ }^{148}$ Glynn Custred, "Security Threats on America's Borders," in Immigration Policy and the Terrorist Threat in Canada and the United States, ed. Alexander Moens and Martin Collacott (Toronto: Fraser Institute, 2008), 97.
} 
At the Federal Court Appeal, Justice Max ruled that Suresh should be removed from Canada due to his connections and engagements with the LTTE. Suresh and his team of lawyers appealed, but failed in January 2000. Judge J.A. Robertson upheld Justice Max’s decision because Suresh's actions put Canada's security at risk. Suresh then appealed to the Supreme Court of Canada on the grounds that his deportation would result to a death sentence. In the Supreme Court of Canada lobby groups including FACT, the Canadian Arab Federation, Canadian Council for Refugees, Amnesty International, Canadian Council of Churches, the Centre for Constitutional Rights, the UN High Commissioner for Refugees, and the Canadian Bar Association in concert argued that Suresh should not be deported. Alex Neve, the head of Amnesty's Canadian chapter expressed, "the right to be free from torture is an absolute human right that applies to all people in all circumstances...We're concerned that no country, including Canada, start to carve out expectations, limitations and restrictions to that right." ${ }^{, 19}$ The Supreme Court ruled that Canada could deport terrorists, knowingly that they would be tortured in their homelands, if they pose a grave danger to the public. Suresh's case was sent back to the Immigration department for further review. Up to today, Suresh remains in Toronto, Canada. He reports to the Immigration Reporting Centre near Pearson International Airport every Thursday morning ${ }^{150}$. Suresh's case indicates the connection between terrorist groups taking advantage of Canada's refugee determination system. The LTTE used Canada's refugee system to transport their members into Canada.

Canada's refugee system unfortunately attracts terrorist groups. Cases such as Ressam and Suresh prove that terrorist groups, such as Al-Qaeda and LTTE, are able to gain access into Canada through the refugee system. If terrorist groups are able to jump the queue, it would be naïve to ignore the possibility that TOCs can use the same method. The Canadian government could have approached the Ressam case, and even potentially the Suresh case, if they immediately detained them to verify their identities. This runs into the second systemic issue that prevents the Canadian government from adequately protecting its

\footnotetext{
${ }^{149}$ Ibid., 83.

150 “Accused terrorist's low-key life," National Post, last modified October 29, 2005 , http://www.canada.com/national/nationalpost/news/story.html?id=0b768a4b-4646-474a-a99e-2438f37983f3.
} 
victims of trafficking and its citizens: the lack of means and willingness to detain individuals at border crossings.

Canada has the right to detain refugee claimants based on Article of 32 and 16 of the UN Refugee Convention. It rarely uses this to protect Canadian citizens and to identify bogus refugees. Since the Immigration Refugee Protection Act (IRPA) was implemented in 2002, an average of 450 persons were detained at a time, a fraction compared to the number of refugees accepted on a yearly basis ${ }^{151}$. Detention has mainly been used when there are illegal boat arrivals. Illegal boat arrivals receive most media attention, and as a result, the Canadian government often detains illegal migrants to show the general public that they are in control of the situation. This was the case in the Golden Venture in $1999^{152}$. The reality though is that majority of refugee claimants refugees enter Canada through borderlands and commercial air flights. Refusing the use of detention allows bogus refugees to avoid criminal, health, and security screening. Canada does not generally detain refugee claimants for several reasons. Based on Singh v. Minister of Employment and Immigration, refugee claimants have the right to legally roam in Canada prior to their IRB hearing. In addition, Canada's does not have the adequate financial means and the physical space to detain refugee claimants. For example, management from the Greater Toronto Enforcement Center continuously reminds officers that detention facilities are limited and maintenance of such facilities is too costly ${ }^{153}$. Another factor is the lack of support from the general Canadian public. Canadian citizens often are not well-educated about the government's structure and processes for detention facilities. They are often misled by exaggerations of the media that paint detention centers as inhumane environments. Most of the general public also opposes the idea of detaining refugees given the image the media convey in the first place. Thus many oppose the idea of detaining refugee claimants. It is reasonable to speculate that Canadians would refuse to spend their tax dollars in detention centres, especially if they are uncomfortable with the Canadian government detaining people that seek for the

\footnotetext{
${ }_{151}$ Alison Mountz, Seeking Asylum: Human Smuggling and Bureaucracy and the Border, 16. 152 Ibid., 79.

${ }^{153}$ Arne Kislenko, "Guarding the Border: Intelligence and Law Enforcement in Canada’s Immigration System,” 317 \& 319 .
} 
country's protection. In reality, detention centres in Canada are no more than low-security facilities. This is the case for Toronto's low-security Immigration Holding Center in Rexdale, Etobicoke. The detention centre is a former Heritage Inn hotel that is only capable of holding up to 120 people. Due to limited space, finance, and opposition from the Canadian general public, detaining refugee claimants rarely occurs. It is not a secret that Canada rarely detains refugee claimants. As a result, this attracts bogus refugees into Canada. Many do not show up to their hearing because they know their narratives are dubious in nature. In 2003, the Auditor General reported that 36,000 refugee claimants did not show up to court order removals ${ }^{154}$.

The use of detention is not the only method to verify the legitimacy of a refugee claimant. STCA is another method that can enhance Canada's and the U.S.' refugee systems, thereby aid both governments effectively to handle refugee claims and reduce the number of abuse in its systems. The bilateral agreement came into effect on December 29, 2004 as part of the Smart Border Action Plan ${ }^{155}$. The agreement essentially prohibits refugee claimants who have passed through another country (other than country of origin) prior to entering into Canada to make a refugee claim. However, there are six exceptions to this rule. Based on these exceptions, refugee claimants could make a claim if they came through by boat, have legally recognized family members, are minors (under the age of 18 years old), hold proper documentation, or if they would receive the death penalty upon returning to the U.S. or a third country. These exceptions unintentionally give greater latitude for criminal and terrorist syndicates to gain access into Canada, especially at port of entry. Furthermore, the exceptions permit many people to come into Canada, which makes it more convenient for traffickers and smugglers to transport their victims and clients into the country. Border security is at the heart of where TOCs and terrorist groups come in physical contact with Canadian immigration and intelligence officers. It is therefore essential to

\footnotetext{
${ }^{154}$ James Bissett, "Security Threats in Immigration and Refugee Policies," in Immigration Policy and the Terrorist Threat in Canada and the United States 2008, ed. by Alexander Moens and Martin Collacott (Toronto: Fraser Institute, 2008), 85.

155 “Canada-U.S Safe Third Country Agreement," CBSA, last modified July 23, 2009, http://www.cbsaasfc.gc.ca/agency-agence/stca-etps-eng.html\#dh-ex.
} 
understand the function of Canada's border security, since it's the primary line of defense against threats to national security.

Border security falls under the jurisdiction of the Canadian Border Service Agency (CBSA), which is under the management of Public Safety Canada ${ }^{156}$. CBSA partners with intelligence services such as CSIS, the Royal Canadian Mounted Police (RCMP), and the Criminal Intelligence Service Canada (CISC) in accessing potential threats to visitor, refugee, and citizenship programs in Canada. Unfortunately, intelligence is undervalued in Canada. According to intelligence expert Anthony Campbell, Canadian foreign, defense or security policies do not pay much attention to immigration intelligence. As a result, information used for public policies are predominately based from the academia and the government. CBSA is the forefront in handling immigration people coming in and out of Canada's ports of entry. Unfortunately, CBSA faces many internal structural issues that make it even more difficult to combat human trafficking and smuggling operations. This is the especially the case at Toronto's Lester B. Pearson International Airport, one of Canada’s largest port of entry.

Basic training for front-line CBSA officers in Toronto's Lester B. Pearson International Airport is limited. A nine week program only focuses on custom issues rather than in-depth training in immigration, investigations, interviews with visitors and refugees, analyzing documents, and intelligence debriefings ${ }^{157}$. As a result, officers are left to learn on the job. They are pressured quickly and effectively to screen individuals entering and exiting the border within minutes. This is layered with constant rotating shifts, little to no encouragement from managers, relatively low pay, and a significant amount of stress from their managers and public at large. Managers often neglect the decisions made by front-line CBSA officers due to their personal beliefs and political pressure further up the ladder. For example, management often "reminds officers that detention facilities are scare and that the economic costs are too high...also privately chastize some officers for writing too many enforcement reports." ${ }^{\prime 158}$ There is a

\footnotetext{
${ }^{156}$ Arne Kislenko, "Guarding the Border: Intelligence and Law Enforcement in Canada's Immigration System," 314.

${ }^{157}$ Ibid., 317.

${ }^{158}$ Ibid.
} 
discrepancy between managers and front-line officers because majority of these managers were hired in the late 1990s which did not have practical immigration experience or education. To complicate matters, CBSA hires university students every spring and summer-the busiest time of the year-under the Public Service Commission's job-creation programs. Students with no real life experience and in the immigration field go through a few days of basic training and then become Canada's gatekeepers ${ }^{159}$. Internal issues at Toronto's Lester Pearson International Airport pose a grave obstacle for CBSA and its partners to adequately protect victims of trafficking and Canadian citizens from TOCs and terrorist groups. As mentioned beforehand, TOCs and terrorist groups use proper and fraudulent documents to gain access into Canada. The combination of lacking adequate training for front-line CBSA officers, the amount of stress accumulated from the general public and higher authorities, and the use of inexperienced summer students during the busiest time of the year becomes a giant stumbling block for front-line officers to identify victims of trafficking, and differentiate genuine refugees from bogus refugees. Bogus refugees can be individuals seeking for a better life in Canada, TOCs, and/or terrorist groups. There are five recommendations offered in the Canadian literature to unclog some of the three systemic issues discussed. They aim to resolve some of the issues in the immigration, refugee, and border security issues. These approaches are offered separately, but can either complement or conflict with one another.

\section{Recommendations and Challenges}

The first recommendation is to replace IRB panel members with public officials to conduct first instance determination process ${ }^{160}$. Decisions by public officials can be more consistent than IRB panel members because they can be trained and be carefully monitored to ensure their decisions reflect government policy. This replacement would ideally cut the backlogs currently in the IRB. The second recommendation is to adopt Australia's refugee system. Approved by UNHCR, Australia's refugee system takes a two track approach for refugees and refugee claimants. Refugees who arrive lawfully are

\footnotetext{
${ }^{159}$ Ibid., 318.

${ }^{160}$ Stephen Gallagher, "Canada’s Broken Refugee Policy System,” 61.
} 
eligible for permanent protection, while refugee claimants are only eligible for Temporary Protection Visas (TPV) ${ }^{161}$. TVPs are valid for three years. The claimant cannot apply for permanent protection until 30 months have passed, within the three years, and the claimant is not entitled to government support (income or medical care), access to a family reunion, nor the right to return to Australia if claimant decides to leave the country. This system is designed to deter bogus refugees and effectively streamline genuine refugees.

The third recommendation is to implement the unfounded policy and to use detentions more often. Unfounded policy essentially grants immigration officers to remove refugee claimants upon arrive if the claimant does not demonstrate a legitimate case ${ }^{162}$. This system is widely used in Europe, the UK, and the U.S., yet in Canada, any claim can be made. There was one case where a refugee claimant argued that if he remained in Poland, he would relapse into alcoholism. He succeeded in gaining access full access to the refugee determination hearing and federal court review. Similar ridiculous claims are not uncommonly made by other bogus refugees in Canada. In terms of detention, some argue that it should be used more often to identify the credibility of refugee claimants and to hold those who have been ordered to a court removal. The development of a "Fortress North America" is the fourth recommendation: a trilateral agreement for Canada and Mexico to adopt American immigration and refugee policies and laws, and border security policies. The approach would create a common immigration and refugee policy, a common system to screen visitors, citizens and refugees, and common usage of border security practices $^{163}$. Having a harmonious approach to border security theoretically enhances cooperation and easier communication between the three states. However, there are many issues to this approach. Canada's would lose its sovereignty towards the U.S., because it would have to change its immigration and refugee law to reflect the U.S.. There is also an enormous financial cost associated to developing

\footnotetext{
${ }^{161}$ Scott D. Watson, The Securitization of Humanitarian Migration: Digging Moats and Sinking Boats, 131.

${ }^{162}$ Stephen Gallagher, "Canada’s Broken Refugee Policy System," 55.

163 Athanasios Hristoulas, "Canada, Mexico, and North American Security," in The Rebordering of North America 2003, ed. by Peter Andreas and Thomas J. Biersteker (New York: Routledge, 2003), 33.
} 
Fortress North America. Technologies such as electronic surveillance, smart cards, drones, and additional border guards are expensive to finance ${ }^{164}$.

The last, and most controversial recommendation, is to slow down immigration, especially from certain ethnic groups ${ }^{165}$. This does not presume that everyone in a particular ethnic group is a criminal or terrorist. However, TOCs and terrorist groups often work within the same ethnic groups as evident with the Russians TOCs, Chinese TOCs, and extreme Islamists groups such as Hezbollah, Hamas, and MS-13. It would be naïve and arrogant to ignore that TOCs and terrorist groups are not hiding and operating in their ethnic enclaves in Canada. For example, between 1973 and 2003, approximately \$U.S. 70 billion was donated by the Saudi Wahhabi organization for Islamist missionary work ${ }^{166}$. Large portions were used to build mosques and Muslim communities in Europe and North America. The issue was that Wahhabi imams, preached exclusively and extensively on the idea of jihad (holy war) in these mosques. As a result, Canadian Muslim immigrants and citizens are not only unknowingly funding potential terrorist groups, but are also exposed to their extreme teachings as well. Slowing down immigration for particular groups drains potential recruits and funding for criminals and terrorist groups. This method was used against the initial wave of the Sicilian Mafia in New York during the early $1920 \mathrm{~s}^{167}$.

The U.S. government paused immigration from Italy for a time being in order for Italian immigrants and their children to assimilate into the American culture. This prevented the Sicilian Mafia to recruit new Italian immigrants who maintained their traditionally suspicion towards the government and authority, and also the Sicilian code of silence. Krikorian, the Executive Director of the Center for Immigration, proposes that Canada should slow down the excessive immigration of certain ethnic groups that reinforces enclaves for TOCs and terrorist groups to operate in. Though slowing down immigration may be an effective approach against TOCs and terrorist groups, it is potentially discriminatory as

\footnotetext{
${ }^{164}$ James Bissett, "Security Threats in Immigration and Refugee Policies," 88.

${ }^{165}$ Mark Krikorian, "Mass Immigration Defeats Homeland Security," in Immigration Policy and Terrorist Threat in Canada and the United States, ed. by Alexander Moens and Martin (Toronto: Fraser Institute, 2008), 45.

${ }^{166}$ Salim Mansur, "Immigration and Muslim Extremists in the Post-9/11 Word," in Immigration Policy and Terrorist Threat in Canada and the United States, ed. by Alexander Moens and Martin Collacott (Toronto: Fraser Institute, 2008), 31.

${ }^{167}$ Mark Krikorian, "Mass Immigration Defeats Homeland Security," 45.
} 
immigrants, refugees, and refugee claimants would be denied entry into Canada based exclusively on their religion. In addition, the majority of people coming into Canada are not connected to criminal or terrorist activity. In a civil society such as Canada, restricting certain ethnic groups from coming into the country in hopes to stop a handful of criminals and terrorist discriminates against innocent migrants.

It is unlikely that the Canadian government would accept any of these recommendations. With respect to Fortress America, Canada does not want to lose its sovereignty to the U.S. ${ }^{168}$. Furthermore, the U.S. holds the greatest number of unidentified illegal immigrants in the world. This would compromise Canada's border security and immigration and refugee system. It is also unlikely that Canada would restrict certain ethnic groups from migrating into the country in order to potentially stop a group of criminals and terrorists. The approach is discriminatory towards one's ethnic or religious background. As for the remaining recommendations, Canadian political parties' agendas would not permit them.

Politicians have created the slogans and ideas of multiculturalism, openness, and tolerance for their political agenda. They promote these ideas, especially towards minority groups to gain voting support. This method is known as bloc voting ${ }^{169}$. All major political parties in Canada use this method. In the 1970s, the Liberals discovered that they could use immigrant groups as a means to their political ends. The introduction and formalization of multiculturalism essentially was used as a political platform for the Liberals. The Party would then be able to fund taxpayers' money to support the growth of ethnic communities such as religious celebrations, cultural events, and media outlets. The Citizenship Act in 1977 was another method to gain political votes. The Act was designed annually to take in immigrants equivalent to $1 \%$ of the Canadian population and fast track this process by reducing the waiting time for citizenship eligibility from five the three years. Voting patterns after the Citizenship Act indicated that new immigrants had the tendency to vote for the party that was pro-immigration. The delay in blacklisting of particular terrorist groups is another example of bloc voting. The Liberals delayed Bill-C36 two years later after 9/11. The bill essentially blacklists known terrorist groups that pose a threat to Canada. The

\footnotetext{
${ }^{168}$ John J. Noble, "A Secure Border? The Canadian View," in Immigration Policy and Terrorist Threat in Canada and the United States, ed. by Alexander Moens and Martin Collacott (Toronto: Fraser Institute, 2008), 72.

${ }^{169}$ James Bissett, "Security Threats in Immigration and Refugee Policies," 76.
} 
Liberals did not provide any explanation to why they did not blacklist terrorist organizations such as $A l$ Qaeda, Hamas, Hezbollah, Babar Khalsa, and or the Armed Islamic Front. The reason was that the Liberals did not want to lose their votes from ethnic communities. This was the case for Barbar Khalsa, a Sikh organization and a terrorist group responsible for the 1985 Air India bombing. The Liberals did not blacklist this group until June 2003 because they feared to lose the thousands of Canadian Sikh supporters living in British Columbia and Ontario. The only reason why Barbar Khalsa was blacklisted 18 years after the Air India bombing was because it became publicly known that CSIS reported that the group was one of the 50 terrorist organizations operating in Canada. ${ }^{170}$ The Conservatives are not exempt from using bloc voting. Their actions in appealing to the immigrant population are especially clear in preparation for the 2011 federal election campaign.

After the Conservatives won a minority government in 2006, the party appointed Jason Kenney as Parliamentary Secretary for the Stephen Harper ${ }^{171}$. In 2008, Kenney became the Minister for Citizenship, Immigration and Multiculturalism. With his guidance, the Conservatives began to shift gears to win the hearts of immigrant populations. In an interview between Kenney and Alec Castonguay, Kenney explains his appeal towards immigrants:

"Previously, the Conservative party was completely absent (from growing ethnic communities). I understood that I would have to be everywhere at all times. Personal contact is crucial for new immigrants...In the last election campaign (2011), I'd done so many that I became confused: I bowed to the wrong God in a church. I looked completely ridiculous...",172

For the 2011 federal election, the Conservatives targeted more than 30 ridings, Ontario being the key battleground ${ }^{173}$. Kasra Nejatian, a staffer in Kenney's Immigration Minister Office, explained that in Ontario, they specifically targeted ten ridings that were 'very ethnic' because each riding had an ethnic group making up $20 \%$ or more of its population. This technique of 'narrow-casting' was a significant

\footnotetext{
${ }^{170}$ Ibid., 79.

${ }^{171}$ Alec Castonguay, “The Inside Story of Jason Kenney's Campaign to Win over Ethnic Votes,” Maclean's, February 2, 2013, http://www.macleans.ca/news/canada/welcome-to-my-world/.

172 Ibid.

${ }^{173}$ Laura Payton, "Ethnic Riding Targeting Key to Conservatives' 2011 Victory," CBCnews, last modified October 23, 2012, http://www.cbc.ca/news/politics/ethnic-riding-targeting-key-to-conservatives-2011-victory-1.1142511.
} 
influence for the Conservatives' success in gaining two-thirds of their 30 targeted ridings, thereby winning the 2011 federation election by a majority government. Though this government has made appeals towards immigrant communities, it has also been active towards reducing the number of refugee claimants. They have been exercising three policies. First is the issuing of security certificates. This involves an immigration proceeding that grants the government the power to remove non-Canadians who do not have the legal right to be in the country, and who pose a threat to the country and its citizens ${ }^{174}$. Under Bill C-3, An Act to amend the Immigration and Refugee Protection Act (certificates and special advocates), the amended legislation grants a judicial lawyer to protect the interest of the individual during closed proceedings. The second policy initiative involves the Designated Countries of Origin (DCO) directive. The DCO is essentially a list of countries that, in the opinion of the Canadian government, "do not normally produce refugees, but do respect human rights and offer state protection."175 According to this policy, refugee claimants from these countries are processed faster, in approximately 30 to 45 days after they enter a claim before the IRB: roughly half the time that it takes to process other refugee claimants. Refugee claimants from DCO countries that fail in their claim do not have access to the RAD, nor can they apply for a work permit upon arrival in Canada. Lastly, the government has adopted the Safe Third Country Act: a policy which dictates that refugee claimants must make a claim in the first country they arrive at (the U.S. or Canada) unless they meet one of the six exceptions as mentioned beforehand (see page 47$)^{176}$. These policies have the good intention of reducing the number of bogus refugees in order to streamline genuine refugees. Unfortunately, TOCs and terrorist groups, whose members might pose as refugee claimants, are still able to by-pass Canada's immigration and refugee determination system.

Canada's current political climate is directing the country into many serious security, human rights, and economic issues. There are two prominent examples that display some of these issues. Firstly,

\footnotetext{
174 “Security Certificates," Public Safety Canada, last modified February 04, 2014, http://www.publicsafety.gc.ca/cnt/ntnl-scrt/cntr-trrrsm/scrt-crtfcts-eng.aspx.

175 "Designated Countries of Origin," CIC, last modified June 2006, 2014, http://www.cic.gc.ca/english/refugees/reform-safe.asp.

176 “Canada-U.S Safe Third Country Agreement," CBSA.
} 
as major political parties hope to gain political support from the immigrant populations, they may unintentionally become puppets for TOCs and terrorist groups that have a firm control over their ethnic diaspora communities. In 2000, for example, Paul Martin, then acting Minister of Finance and Member of Parliament Maria Minna attended a fundraiser dinner organized by the LTTE ${ }^{177}$. With political support by the Liberal Party, LTTE members freely built multiple fronts in the Toronto Tamil community to carry their illicit activities such as human smuggling, murders, extortion, and gun trafficking ${ }^{178}$. The appearance of Paul Martin and Maria Minna in the fundraiser sparked an intense debate in Parliament and media about the Liberals supporting terrorist activity. Martin unknowingly and ignorantly became the LTTE's puppet as he responded to the public stating that "to condemn these people, to call them terrorists, is antiCanadian." ${ }^{179}$ His comments not only deflected the truth about the LTTE, but as well fuelled their propaganda for Suresh's case. The LTTE used to be a deadly terrorist organization that produced millions of dollars to fund their fight in Sri Lanka. International terrorism expert Rohan Gunaratne noted that these fronts have raised up to $\$ 22$ million in 2001, where the money was laundered in European banks to purchase arms and explosives ${ }^{180}$.

Despite the public knowledge of Project 1050 in 2001, the Liberals continue to support Sri Lankan organizations that have ties to LTTE. In 2006, local Liberal MPs in Markham Toronto came out to support Ravi Pararmu's rally on the establishment of an LTTE state in Sri Lankan. The rally also included the support of S.P Thamilselvan's death, a political head and chief negotiator for the LTTE in Sri Lanka. John McKay, Liberal MP for Scarborough-Guildwood commented "I wish [Stephen] Harper was more enthusiastic about committing himself to the peace process and less enthusiastic about designating people as terrorists. Labeling people is dead easy...it accomplishes nothing. It compromises

\footnotetext{
${ }^{177}$ Judi McLeod, "Dinning with terrorists," Canadafreepress, last modified January 10, 2005, http://www.canadafreepress.com/2005/cover011005.htm.

${ }_{178}$ Arne Kislenko, "Guarding the Border: Intelligence and Law Enforcement in Canada's Immigration System," 323.

${ }^{179}$ Stewart Bell, Cold Terror, 81-83.

${ }^{180}$ Judi McLeod, "Dinning with Terrorists," 2005.
} 
your positioning as a neutral third party." ${ }^{181}$ The Liberal support for Sri Lankan organizations that have ties to LTTE encouraged the terrorist group to morph its tactics to fight against the Sri Lankan government. In 2008, Sri Lankan government executed a heavy offensive to finish off the LTTE military in Sri Lanka. In response, senior LTTE officials orchestrated an international protest on Toronto's major highways for weeks. Thousands of protesters came out to support the LTTE by blocking Toronto's major highways and openly waiving the LTTE's flag. ${ }^{182}$

The LTTE and millennium bomber case do not hold a good image for Canada, especially in the U.S.. After 9/11, the U.S. blamed Canada for being a hotbed for terrorists, and a transit country where terrorist groups can easily slip into the U.S. through Canada's leaky immigration and refugee system ${ }^{183}$. Though none of the hijackers of 9/11 had migrated into the U.S. through Canada's immigration or refugee system, Canada nonetheless has already lost political face. Canada and the U.S. have the largest trading relationship worldwide. Each day more than $\$ 4$ billion worth of goods and services cross the CanadianUS border ${ }^{184} .70 \%$ of Canada's trading relations are based with the U.S.. The majority of Canadian and U.S. business is conducted through the borders of Windsor and Detroit. On top of economic trade, roughly two million people cross Canadian-U.S. borders annually. During 9/11, the U.S. heightened its borders to protect itself from another terrorist attack. This influenced the cross-border commercial flow between Canada and the U.S. In 2003, for example, increased border crossing of people and security checks has contributed to a $60 \%$ delay for cross-border commercial traffic. Canada is caught in a "Catch22" dilemma to balance protecting its border security, appease advocacy groups for refugees and immigrants, and sustain its economy. Many of these factors are often ignored or not transparently raised in the public realm, which raises the second issue.

\footnotetext{
181 “Liberal Mps Attend Vigil for Slain Tamil Tiger,” National Post, last modified November 6, 2007, http://www.nationalpost.com/news/story.html?id=63dcd577-db95-4808-b8cc-819b4ed336cf.

${ }^{182}$ Arne Kislenko, "Guarding the Border: Intelligence and Law Enforcement in Canada's Immigration System," 324.

${ }_{183}$ Alison Mountz, Seeking Asylum: Human Smuggling and Bureaucracy and the Border, 12.

${ }^{184}$ Victor Konrad and Heather N. Nicol, Beyond Walls: Re-inventing the Canada-United States Borderlands. (Aldershot, Hampshire: Ashgate Publishing Limited, 2008), 8.
} 
The Canadian general public is often unaware that immigration, refugees, refugee claimants, human smuggling, and human trafficking are inherently intertwined with border and economic security, Narco-Terrorism and the Crime-Terror Nexus, a weak structural immigration and refugee system, and bloc voting. The inability to see the big picture is extremely dangerous as the general public is exposed to so many different perspectives that may reveal a piece of the truth or completely derail the reality. Cases such as the support for Suresh and Ravi Pararmu are some examples. Without adequate knowledge, the Canadian public would be vulnerable to becoming puppets in supporting criminal and terrorist activities. Advocacy groups for immigration and refugees are sometimes focused so much in the academic and humanitarian arenas that they often miss the bigger picture of law enforcement and national security. On the other hand, law enforcement and intelligence agencies also sometimes prioritize in catching and punishing TOCs and terrorist groups over the effort to aid victims and protect vulnerable populations. The Canadian media often provides misinformation on the realities of terrorist threats, border security, and refugee issues. John McKay's comment towards Stephen Harper is an example. Another example is the conflation of legal terminologies. In some high-profile refugee claimant cases, the media carelessly misuses terminologies such as 'arrest,' 'detained,' and 'deportation,' when in fact each has their own legal meanings and administrative processes ${ }^{185}$. The terms 'refugee' and 'refugee claimant' are also conflated. The media often makes no distinction between the two terms. Instead, they attach emotionally charged stories to convince the general public, who are not well educated in the legal field of immigration, that those who propose to strengthen the immigration and refugee systems and enhance border security are racist and xenophobic.

\section{Conclusion}

Members of political parties and academics and advocacy groups for victims of trafficking, refugees, and immigrants need to understand the realities of the clandestine nature of human trafficking

\footnotetext{
185 Arne Kislenko, "Guarding the Border: Intelligence and Law Enforcement in Canada's Immigration System," 318.
} 
and smuggling operated by TOCs and terrorist groups. Human trafficking, smuggling and bogus refugees are only part of a larger issue. Solely advocating a victims' right approach to solve these problems only refers more business to TOCs and terrorist groups. Solely advocating a criminal approach is not the solution either, though it is clearly evident that the current immigration and refugee system is heavily geared towards a victims' rights approach. There is no one size fits all solution to this multifarious conundrum. What is necessary though is to create a civil climate where all parties are able to bring their perspective openly into the discussion. This will depend on how open minded each party decides to be. 


\section{Bibliography}

“Accused terrorist's low-key life." National Post. Last modified October 29, 2005. http:// www.canada.com/national/nationalpost/news/story.html?id=0b768a4b-4646-474aa99e-2438f37983f3.

Andreas, Peter. "The Mexicanization of the US-Canada Border." International Journal 60, no. 2 (2005): 449-462. Accessed July 28, 2014. http://www.jstor.org.ezproxy.lib.ryerson.ca/stable/ $10.2307 / 40204302$ ?origin=api.

Aronowitz, Alexis A. Human Trafficking, Human Misery. London: Praeger, 2009. 51-161.

Barrett, Nicole A. An Exploration of Promising Practices in Responses to Human Trafficking in Canada. Vancouver: International Centre for Criminal Law Reform and Criminal Justice Policy, 2010. http://site.ebrary.com.ezproxy.lib.ryerson.ca/lib/oculryerson/docDetail.action? docID=10434242.

Barnett, Laura."Bill C-49 an Act to Amend the Criminal Code (Trafficking in Persons) (Rev.ed)". Ottawa: Library of Parliament, Parliamentary Research Branch (2005): 1-15. Accessed July 28, 2014. http://www.parl.gc.ca/About/Parliament/LegislativeSummaries/bills_Is.asp? $\mathrm{IS}=\mathrm{C} 49 \& \mathrm{Parl}=38 \& \mathrm{Ses}=1,2-$.

Barone, T. "The Trafficking Victims Protection Act of 2000: Defining the Problem and Creating a Solution." Int'l \& Comp. L.J (2003): 579-594. Accessed July 28, 2014. http:// www.heinonline.org.ezproxy.lib.ryerson.ca/HOL/Page?page $=579 \&$ handle=hein.journals $\% 2$ Ftclj17\&collection=journals $\# 600$.

Bell, Stewart. Cold Terror. Canada: John Wiley \& Sons Canada, Ltd. 77-85.

Bhattacharji, Preeti. "Liberation Tigers of Tamil Ealam (aka Tamil Tigers) (Sri Lanka, Separatists)." Council on Foreign Relations. Last modified May 20, 2009. http://www.cfr.org/separatistterrorism/liberation-tigers-tamil-eelam-aka-tamil-tigers-sri-lanka-separatists/p9242.

Bouclin, Suzanne. "Exploited Employees Or Exploited Entrepreneurial Agents? A Look at Erotic Dancers." Canadian Woman Studies 23, no. 3 (2004): 132-137. Accessed July 28, 2014. http://ezproxy.lib.ryerson.ca/login?url=http://search.proquest.com/docview/217457085?accountid $=13631$.

Bissett, James. "Security Threats in Immigration and Refugee Policies." In Immigration Policy and the Terrorist Threat in Canada and the United States 2008, edited by Alexander Moens and Martin Collacott, 75-95. Toronto: Fraser Institute, 2008.

“Canada-U.S. Safe Third Country Agreement." CBSA. Last modified July 23, 2009. http://www.cbsaasfc.gc.ca/agency-agence/stca-etps-eng.html\#dh-ex.

Castonguay, Alec.“The Inside Story of Jason Kenney's Campaign to Win over Ethnic Votes.” Maclean's. February 2, 2013. http://www.macleans.ca/news/canada/welcome-to-my-world/ f. 
Chin, Ko-Lin. "The Social Organization of Chinese Human Smuggling.” In Global Human Smuggling, edited by David Kyle and Rey Koslowski, 186-203. Baltimore, Maryland: The Johns Hopkins University Press, 2009.

"Creation, Aims, Methods \& Effectiveness of the Palestinian Liberation Organization (PLO) 1964-1974." Israel \& Judaism Studies.au. Accessed September 6, 2004. http://www.ijs.org.au/The-PalestineLiberation-Organisation/default.aspx.

Custred, Glyn. "Security Threats on America's Borders." In Immigration Policy and the Terrorist Threat in Canada and the United States 2008, edited by Alexander Moens and Martin Collacott, 95-108. Toronto: Fraser Institute, 2008.

"Designated Countries of Origin." CIC. Last Modified June 06, 2017. http://www.cic.gc.ca/english/refugees/reform-safe.asp.

Erokhina, Liudmila. "Trafficking in Women in the Russian Far East: A Real or Imaginary Phenomenon?.” In Human Traffic and Transnational Crime: Eurasian and American Perspective, edited by Sally Stoecker and Louise Shelley, 79-94. Lanham, MD: Rowman \& Littlefield Publishers, Inc. 2005.

Finckenauer, James O., and Elin J. Waring. Russian Mafia in America. Boston: Northeastern University Press, 1998.

Free the Slaves and Human Rights Centre. "The Challenge of Hidden Slavery: Legal Responses to Forced Labor in the United States. In Trafficking and the Global Sex Industry 2006, edited by Karen Beeks and Delila Amir, 119-134. Lanham, MD: Rowman \& Littlefield Publishers, INC., 2006.

Fogel, Curtis A. and Andrea Quinlan."Dancing Naked: Precarious Labour in the Contemporary Female Strip Trade." Canadian Social Science 7, no. 5 (2011): 51-56. Accessed July 28, 2014. http:// ezproxy.lib.ryerson.ca/login?url=http://search.proquest.com/docview/1221242443? accountid=13631.

Gallagher, Stephen. “Canada's Broken Refugee Policy System.” In Immigration Policy and Terrorist Threat in Canada and the United States, edited by Alexander Moens and Martin Collacott, 53-74. Toronto: Fraser Institute, 2008.

Gozdziak, Elzhieta M., and Elizabeth A. Collett. "Research on Human Trafficking in North America: A Review of Literature." In Data and Research on Human Trafficking: A Global Survey 2005, edited by Frank Lazko and Elzbieta Gozdziak, 99-123. Geneva: International Organization for Migration, 2005.

Hesterman, Jennifer L. The Terrorist-Criminal Nexus. New York: Taylor \& Francis Group, 2013. 
Hristoulas, Athanasios. "Canada, Mexico, and North American Security." In The Rebordering of North America 2003, edited by Peter Andreas and Thomas J. Biersteker, 24-45. New York: Routledge, 2003.

Hughes, Donna M. "The Demand for Victims of Sex Trafficking?.” In L. McDonald (Ed.), Toronto: Status of Women Canada. n.a. (2005): 1-65. Accessed July 27, 2014. http://www.uri.edu/artsci/wms/hughes/demand_for_victims.pdf.

Jakobi, Anja. Common Goods \& Evil?. New York: Oxford University Press, 2013.

Jayasinghe, Udara, and Sasha Baglay. "Protecting victims of human trafficking within a 'Nonrefoulement' framework: Is complementary protection an effective alternative in Canada and Australia?." International Journal of Refugee Law 23, no. 3 (2011): 489-520. Accessed July 29, 2014. http://journals2.scholarsportal.info.ezproxy.lib.ryerson.ca/pdf/09538186/ v23i0003/489_pvohtweaicaa.xml

Jeffrey, Leslie Ann, and Barbara Sullivan. "Canadian Sex Work Policy for the 21st Century: Enhancing Rights and Safety, Lessons from Australia." Canadian Political Science Review, no.3 (2009): 57 69. Accessed July 28, 2014. http://www.cfuw.org/Portals/0/SexWorkersRIghts.pdf.

Kislenko, Arne. "Guarding the Border: Intelligence and Law Enforcement in Canada's Immigration System.” In Oxford Handbook of National Security Intelligence 2010, edited by Loch K. Johnson, 310-327. Toronto: Oxford University Press, 2010.

Konrad, Victor, and Heather N. Nicol. Beyond Walls: Re-inventing the Canada-United States Boderlands. Aldershot, Hampshire: Ashgate Publishing Limited, 2008.

Krikorian, Mark. "Mass Immigration Defeats Homeland Security." In Immigration Policy and Terrorist Threat in Canada and the United States, edited by Alexander Moens and Martin Collacott, 37-51. Toronto: Fraser Institute, 2008.

“Liberal Mps Attend Vigil for Slain Tamil Tiger," National Post. Last modified November 6, 2007. http://www.nationalpost.com/news/story.html?id=63dcd577-db95-4808-b8cc-819b4ed336cf.

Laub, Zachary. "Hamas." Council on Foreign Relations. Last modified August 1, 2014. http:// www.cfr.org/israel/hamas/p8968.

Law Tuulia. "Cashing in on Cachet?: Ethnicity and Gender in the Strip Club." Canadian Journal of Women and the Law 24, no.1 (2012): 135-153. Accessed July 27, 2014. http:// muse.jhu.edu.ezproxy.lib.ryerson.ca/journals/canadian_journal_of_women_and_the_law/ v024/24.1.law.html

Macklin, Audrey. "Dancing Across Borders: 'Exotic Dancers,' Trafficking, and Canadian Immigration Policy." International Migration Review 37, no. 2 (2003): 464-500. Accessed July 27, 2014. http://journals2.scholarsportal.info.ezproxy.lib.ryerson.ca/details/01979183v37i0002/464_dabdta cip.xml

Makarenko, Tamera. "Organized Crime or Crimes Organized?," In Human Trafficking and Human Security, edited by Anna Jonsson, 26-47. New York: Routledge, 2009. 
Makarenko, Tamera. "The Crime-Terror Continuum: Tracing the Interplay between Transnational Organized Crime and Terrorism." Routledge Taylor \& Francis Group 6, no. 1 (2004): 129-145. Accessed July 28, 2014. http://journals2.scholarsportal.info.ezproxy.lib.ryerson.ca/pdf/17440572/ v06i0001/129_tccttibtocat.xml.

Mallory, Stephen L. Understanding Organized Crime. Mississauga: Jones \& Bartlett, 2012.

Mansur, Salim. "Immigration and Muslim Extremists in the Post-9/11 Word." In Immigration Policy and Terrorist Threat in Canada and the United States, edited by Alexander Moens and Martin Collacott, 21-36. Toronto: Fraser Institute, 2008.

McDonald, Lynn, Moore Brooke, and Natalya Timoshkina. "Migrant Sex Workers from Eastern Europe and the Former Soviet Union: The Canadian Case." Status of Women Canada, no. SW21-63 (2000):1-105. Accessed July 27, 2014. http://publications.gc.ca/collections/Collection/ SW21-63-2000E.pdf.

McLeod, Judi. "Dinning with Terrorists," Canadafreepress. Last modified January 10, 2005. http:// www.canadafreepress.com/2005/cover011005.htm.

Meaghan, Diane Eleanor. "The Political Economy of Stripping: The Social Construction of Sex Trade Work." PhD diss., University of Toronto, 2000. no. NQ53864 (2000):163. Accessed July 27, 2014. http://ezproxy.lib.ryerson.ca/login?url=http://search.proquest.com/docview/304660687? accountid $=13631$.

Mincheva, Lyubov G, and Ted R. Gurr. Crime-Terror Alliances and The State: Ethnonationalist and Islamist Challenges to Regional Security. New York: Routledge Taylor \& Francis Group, 2013.

Mountz, Alison. Seeking Asylum: Human Smuggling and Bureaucracy and the Border. Minneapolis: University of Minnesota Press, 2010.

Muftic, Maja. "The Impact of Restrictive Immigration Policies on Human Trafficking in Canada." University of Ottawa, no. MR61284 (2009): 1-115. Accessed July 28, 2014. http:// ezproxy.lib.ryerson.ca/login?url=http://search.proquest.com/docview/520201637? accountid=13631.

Noble, John. J. “A Secure Border? The Canadian View.” In Immigration Policy and Terrorist Threat in Canada and the United States, edited by Alexander Moens and Martin Collacott, 161-182. Toronto: Fraser Institute, 2008.

"Organized crime intimidated bureaucrats, inside official says." National Post. Last modified December 18, 2004. http://www.canada.com/national/nationalpost/news/story.html?id=158bc48ec6cd-4a49-927b-5f60c3cbb092\&page $=2$.

Payton, Laura. "Ethnic Riding Targeting Key to Conservatives' 2011 Victory.” CBCnews. Last modified October 23, 2012. http://www.cbc.ca/news/politics/ethnic-riding-targeting-key-toconservatives-2011-victory-1.1142511.

Rieger, April. "Missing the Mark: Why the Trafficking Victims Protection Act Fails to Protect Sex Trafficking Victims in the United States". Harvard Journal of Law \& Gender, no. 30(1) (2007): 232-256. Accessed July 23, 2014. http://ww.heinonline.org.ezproxy.lib.ryerson.ca/HOL/Page? page $=231 \&$ handle $=$ hein.journals $\% 2$ Fhwlj30\&collection=journals $\# 235$. 
Repetskaia, Ana. "Classifying the Elements of Human Trafficking Crimes." In Human Traffic and Transnational Crime 2005: Eurasian and American Perspetives, edited by Sally Stoecker and Louise Shelley, 47-60. Lanham. MD: Rowman \& Littlefield Publishers, Inc. 2005.

Roots, Katrin. "Trafficking or Pimping?: An Analysis of Canada's Human Trafficking Legislation and Its Implications." Canadian Journal of Law and Society, no.28 (2013):1-22. Accessed June 12, 2014. http://muse.jhu.edu.ezproxy.lib.ryerson.ca/journals/canadian_journal_of_law_and_society v028/28.1.roots.pdf.

“Security Certificates." Public Safety Canada. Last modified February 04, 2014. http://www.publicsafe ty.gc.ca/cnt/ntnl-scrt/cntr-trrrsm/scrt-crtfcts-eng.aspx.

Shelley, Louise. "Russian and Chinese Trafficking: A Comparative Perspective." In Human Traffic and Transnational Crime: Eurasian and American Perspective, edited by Sally Stoecker and Louise Shelley, 63-75. Lanham, MD: Rowman \& Littlefield Publishers, Inc. 2005.

Sikka, Anette. Trafficking of Aboriginal Women and Girls in Canada. Ottawa: Institute of Governance, 2009. http://site.ebrary.com.ezproxy.lib.ryerson.ca/lib/oculryerson/docDetail.action? docID=10309584.

Stewart, Donna, and Gajic-Velijanoski Olga. "Trafficking in Women: The Canadian Perspective." Canadian Medical Association Journal, no.173 (2005): 25-26. Accessed June 12, 2014. http://www.ncbi.nlm.nih.gov/pmc/articles/PMC1167803/pdf/20050705s00018p25.pdf.

Sulaimanova, Saltanat. "Trafficking in Women from the Former Soviet Union for the Purposes of Sexual Exploitation." In Trafficking and The Global Sex Industry, edited by Karen Beeks and Delila Amir, 61-72. Lanham, MD: Rowman \& Littlefield Publishers, Inc., 2006.

The Canadian Press. "New Canadian Immigration Rules Target Marriage Fraud." Huffingtonpost,. Last modified October 26, 2014. http://www.huffingtonpost.ca/2012/10/26/new-canadianimmigration-rules-marriage-fraud_n_2022401.html\#slide $=1688084$.

Tocher, Annemarie. "Domestic Trafficking in Aboriginal Persons: The Legacy of Colonization and Sexual Exploitation.” The HindSight Group, n.a. (2012):1-42. Accessed July 28, 2014. http://www.firstpeoplesgroup.com/mnsiurban/PDF/reports/Tocher_ALegacy_of_Colonization_and_Sexual_Exploitation_(2012).pdf.

Trepanier, Monique. "Trafficking in women for purposes of sexual exploitation: a matter of consent?." Canadian Women Studies, no.22 (2003):48-54. Accessed July 28, 2014. http://search.proquest.com.ezproxy.lib.ryerson.ca/docview/217456914?pq-origsite=summon.

Tyldum, G., and Brunovskis, A. "Methodological Challenges in Research with Trafficked Persons: Tales from the Field." In Data and Research on Human Trafficking A Global Survey 2005, edited by Frank Laczko and Elzbieta Gozdziak,17-31. Geneva: International Organization for Migration, 2005.

United Nations. "Protocol to Prevent, Suppress and Punish Trafficking in Persons, especially Women and Children, Supplementing the United Nations Convention Against Transitional Organized Crime." UNCJN. Accessed July 24, 2014. http://www.uncjin.org/Documents/Conventions/dcatoc/ final_documents_2/convention_\%20traff_eng.pdf. 
“UNHCR 2012 Refugee Statistics: Full Data.” The Guardian. Last modified June 19, 2013. http:// www.theguardian.com/news/datablog/2013/jun/19/refugees-unhcr-statistics-data? commentpage $=1$.

Väyrynen, Raimo. "Illegal Immigration, Human Trafficking, and Organized Crime." United Nations University/WIDER, no. 72 (2003): 1-21.

Vermeulen, Damme, and Werner Bondt. Organised Crime Involvement in Trafficking in Persons and Smuggling of Migrants. Portland, Oregon: Maklu, 2010. 33-75.

Wang, Peng. (2010). The Crime-Terror Nexus: Transformation, Alliance, Convergence. Asian Social Science, no. 6 (2010):11-17. Accessed July 28, 2014. http: search.proquest.com.ezproxy.lib.ryerson.ca/docview/822929729/fulltextPDFaccountid=13631.

Watson D., Scott. The Securitization of Humanitarian Migration: Digging Moats and Sinking Boats. New York: Routledge, 2009.

“What is Organized Crime?.” RCMP. Last modified October 24, 2011. http://www.rcmp-grc.gc.ca/soccgco/what-quoi-eng.htm.

Weis, Paul. “The Refugee Convention, 1951.”UNHCR. n.a. http://www.unhcr.org/4ca34be29.html.

Winterdyk, John, and Kelly Sundberg. "Human Trafficking: An International Tragedy." Law Now 33, no. 4 (Mar, 2009): 1-5.

http://ezproxy.lib.ryerson.ca/login?url=http://search.proquest.com/docview/219901817?accountid $=13631$.

Zhang, Sheldon. Chinese Human Smuggling Organizations. San Diego: Stanford University Press, 2008. 1-3, 64-99, 105-131, 151-181 \& 208-234.

Zimmerman, Yvonne C. "Situating the Ninety-Nine: A Critique of the Trafficking Victims Protection Act." Journal of Religion \& Abuse, no. 7.3 (2005): 37-56. Accessed 19 July 2014. http://journals2.scholarsportal.info.ezproxy.lib.ryerson.ca/details/15211037/v07i0003/37_stnacott vpa.xml. 